\title{
Radium and Thorium Sorption by Monosodium Titanate (MST) and Modified MST (mMST)
}

\author{
K. M. L. Taylor-Pashow \\ D. T. Hobbs
}

February 2012

Savannah River National Laboratory Savannah River Nuclear Solutions, LLC Aiken, SC 29808

Prepared for the U.S. Department of Energy under contract number DE-AC09-08SR22470. 
SRNL-STI-2012-00072

Revision 0

\section{DISCLAIMER}

This work was prepared under an agreement with and funded by the U.S. Government. Neither the U.S. Government or its employees, nor any of its contractors, subcontractors or their employees, makes any express or implied:

1. warranty or assumes any legal liability for the accuracy, completeness, or for the use or results of such use of any information, product, or process disclosed; or

2. representation that such use or results of such use would not infringe privately owned rights; or

3. endorsement or recommendation of any specifically identified commercial product, process, or service.

Any views and opinions of authors expressed in this work do not necessarily state or reflect those of the United States Government, or its contractors, or subcontractors.

\section{Printed in the United States of America \\ Prepared for \\ U.S. Department of Energy}


Keywords: $M S T$, $m M S T$, Radium, Thorium

Retention: Permanent

\title{
Radium and Thorium Sorption by Monosodium Titanate (MST) and Modified MST (mMST)
}

\author{
K. M. L. Taylor-Pashow \\ D. T. Hobbs
}

February 2012

Savannah River National Laboratory Savannah River Nuclear Solutions, LLC Aiken, SC 29808

Prepared for the U.S. Department of Energy under contract number DE-AC09-08SR22470. 


\section{REVIEWS AND APPROVALS}

AUTHORS:

K. M. L. Taylor-Pashow, Separations and Actinide Science Programs

Date

D. T. Hobbs, Separations and Actinide Science Programs

Date

TECHNICAL REVIEW:

T. B. Peters, Separations and Actinide Science Programs

Date

APPROVAL:

S. D. Fink, Manager

Date

Separations and Actinide Science Programs

S. L. Marra, Manager

Date

Environmental \& Chemical Process Technology Research Programs

K. H. Subramanian, Manager

Date SRR Engineering 


\section{EXECUTIVE SUMMARY}

A series of tests were planned to examine the removal of $\mathrm{Ra}$ and $\mathrm{Th}$ by monosodium titanate (MST) and modified monosodium titanate (mMST). Simulated waste solutions were prepared containing $\mathrm{Ra}$ and $\mathrm{Th}$, along with $\mathrm{Sr}, \mathrm{Np}, \mathrm{Pu}$, and $\mathrm{U}$. Following simulant preparation the simulants were filtered through $0.45-\mu \mathrm{m}$ filters. Analysis of the simulants indicated no Th in the filtered solution. This is due to the very low solubility of Th in alkaline solutions. Based on the reported detection limits for ${ }^{228} \mathrm{Th}$ by gamma analyses, the solubility of $\mathrm{Th}$ in the simulant solutions is $<3.0 \mathrm{E}-10 \mathrm{~g} / \mathrm{L}$ or $<1.3 \mathrm{E}-12 \mathrm{M}$. Therefore, data could not be obtained regarding the removal of Th by MST and mMST; however, testing proceeded to examine the removal of Ra.

Sorption testing indicated that $\mathrm{Ra}$, like $\mathrm{Sr}$, is very rapidly removed from solution by both MST and mMST. The Ra concentration in solution fell below the method detection limit (MDL) within 30 minutes of contact with MST, and within 2 hours of contact with mMST, when tested at $25{ }^{\circ} \mathrm{C}$ using a $5.6 \mathrm{M} \mathrm{Na}$ simulant. Additional testing examined the effects of ionic strength and temperature on the MST and mMST performance. Results from these tests showed that the majority of samples still reached a Ra concentration below the MDL, indicating excellent removal. For the highest ionic strength solution $(6.6 \mathrm{M} \mathrm{Na})$, there did appear to be a slight decrease in the Ra removal by mMST, as indicated by a larger number of samples just above the MDL. The effect of temperature on ${ }^{226} \mathrm{Ra}$ removal is indeterminate for either MST or mMST in the temperature range $\left(25-60{ }^{\circ} \mathrm{C}\right)$ and concentrations studied since the final soluble concentration of Ra remained at or below the detection limits for all tests.

Desorption testing was also performed using decontaminated salt solution (DSS) diluted to sodium concentrations of $2 \mathrm{M}$ and $0.5 \mathrm{M}$, to represent the intermediate and final stages of washing. Results from these tests indicated no desorption of any sorbents, with the exception of $\mathrm{Pu}$ from $\mathrm{mMST}$, which desorbed slightly $(0.02 \%)$. Rather, the testing showed additional sorption of sorbates, likely due to the higher sorbent concentrations in these tests compared to the concentrations used for loading (i.e. $13 \mathrm{~g} / \mathrm{L}$ vs. $0.4 \mathrm{~g} / \mathrm{L}$ ).

SRNL recommends additional testing to confirm the low solubility of Th in a range of simulants representing SRS HLW. We also recommend additional sorption testing with simulants containing a higher concentration of ${ }^{226} \mathrm{Ra}$, to allow for the determination of actual DF values, rather than the minimum DF values reported here. 


\section{TABLE OF CONTENTS}

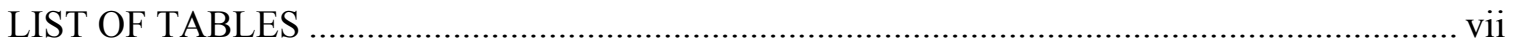

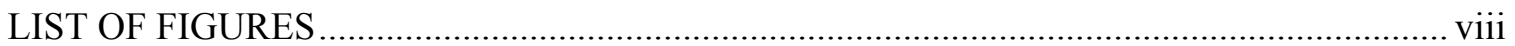

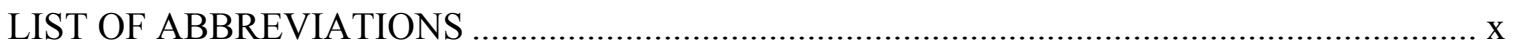

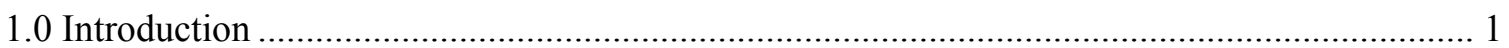

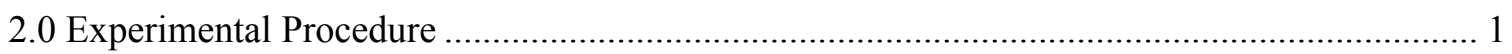

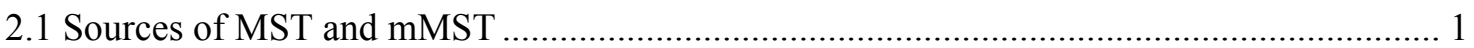

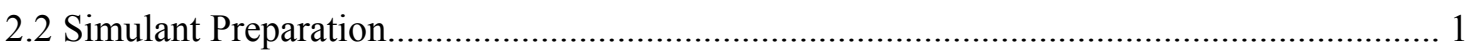

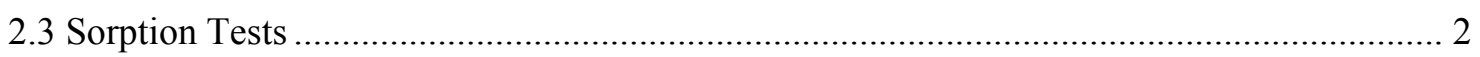

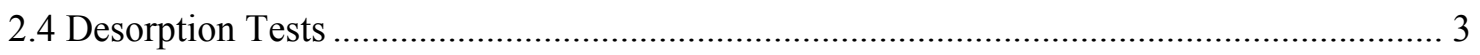

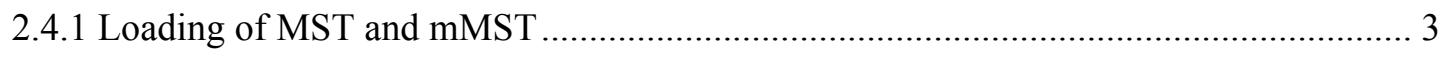

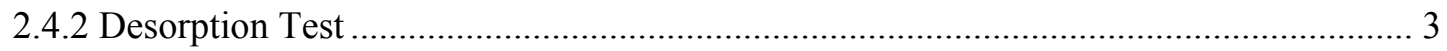

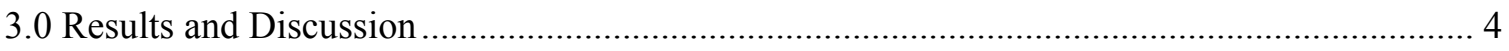

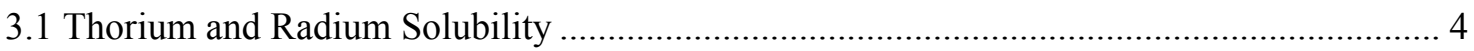

3.2 Comparison of MST and mMST Sorption Performance ................................................ 4

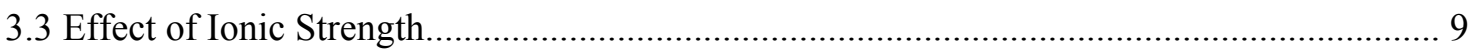

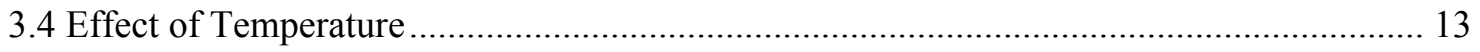

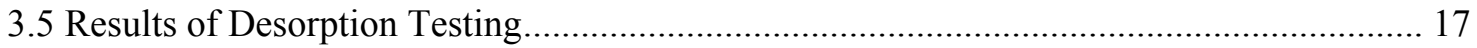

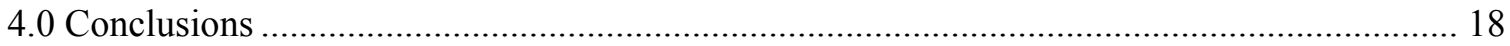

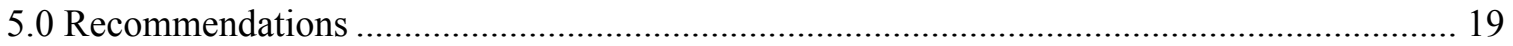

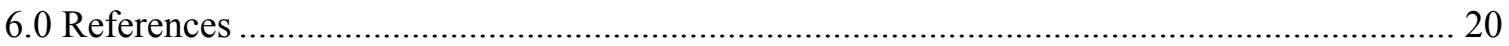




\section{LIST OF TABLES}

Table 2-1. Compositions of Simulants.

Table 3-1. Summary of ${ }^{226} \mathrm{Ra}$ DFs obtained at $25{ }^{\circ} \mathrm{C}$ after contact with SWS-7-2011-5.6. The numbers in parenthesis represent one sigma uncertainty. Many of the measured values fell below the MDL, resulting in greater than values being obtained for the DFs.

Table 3-2. Summary of ${ }^{85} \mathrm{Sr}$ DFs obtained at $25{ }^{\circ} \mathrm{C}$ after contact with SWS-7-2011-5.6. The

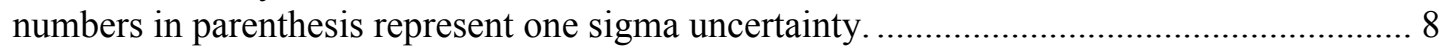

Table 3-3. Summary of Pu DFs obtained at $25{ }^{\circ} \mathrm{C}$ after contact with SWS-7-2011-5.6. The numbers in parenthesis represent one sigma uncertainty .................................................. 8

Table 3-4. Summary of Np DFs obtained at $25{ }^{\circ} \mathrm{C}$ after contact with SWS-7-2011-5.6. The

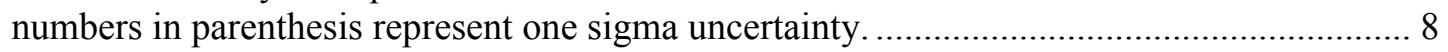

Table 3-5. Summary of U DFs obtained at $25{ }^{\circ} \mathrm{C}$ after contact with SWS-7-2011-5.6. The numbers in parenthesis represent one sigma uncertainty.

Table 3-6. Summary of ${ }^{226} \mathrm{Ra}$ DFs in different ionic strength simulants (4.6, 5.6, and 6.6 M Na). Values in parenthesis represent one sigma uncertainty from a single trial.

Table 3-7. Summary of U DFs in different ionic strength simulants (4.6, 5.6, and 6.6 M Na). Values in parenthesis represent the standard deviation of the average of duplicate trials. .... 13

Table 3-8. Summary of U DFs at various temperatures. Values in parenthesis represent the standard deviation of the average of duplicate trials.

Table 3-9. Summary of ${ }^{226}$ Ra DFs at various temperatures. Values in parenthesis represent the standard deviation of the average of duplicate trials.

Table 3-10. Summary of MST desorption testing. Values in parenthesis represent one sigma uncertainty in the measurement.

Table 3-11. Summary of mMST desorption testing. Values in parenthesis represent one sigma uncertainty in the measurement.

Table A-1. Comparison of ${ }^{85} \mathrm{Sr}$ DFs in different ionic strength simulants (4.6, 5.6, and 6.6 M Na). Values in parenthesis represent the standard deviation of the average of the two trials...... A-4

Table A-2. Comparison of Pu DFs in different ionic strength simulants $(4.6,5.6$, and 6.6 M Na). Values in parenthesis represent the standard deviation of the average of the two trials...... A-4

Table A-3. Comparison of Np DFs in different ionic strength simulants (4.6, 5.6, and 6.6 M Na). Values in parenthesis represent the standard deviation of the average of the two trials..... A-5

Table A-4. Comparison of ${ }^{85} \mathrm{Sr}$ DFs at different temperatures in the $5.6 \mathrm{M}$ Na simulant $(25,45$, and $60{ }^{\circ} \mathrm{C}$ ). Values in parenthesis represent the standard deviation of the average of the two trials 
Table A-5. Comparison of Pu DFs at different temperatures in the $5.6 \mathrm{M} \mathrm{Na}$ simulant $(25,45$, and $60^{\circ} \mathrm{C}$ ). Values in parenthesis represent the standard deviation of the average of the two trials

Table A-6. Comparison of Np DFs at different temperatures in the 5.6 M Na simulant $(25,45$, and $60{ }^{\circ} \mathrm{C}$ ). Values in parenthesis represent the standard deviation of the average of the two trials

\section{LIST OF FIGURES}

Figure 3-1. ${ }^{226} \mathrm{Ra}$ activity versus contact time for Tests $1-5\left(25{ }^{\circ} \mathrm{C}, 5.6 \mathrm{M} \mathrm{Na}\right)$. Open data points identify maximum concentrations (i.e., measured concentrations are at detection limits). ..... 5

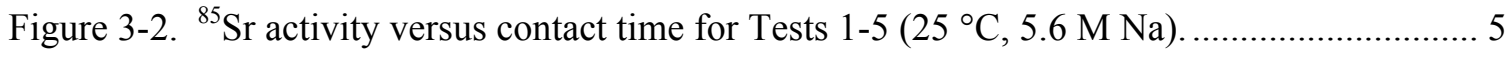

Figure 3-3. Pu concentration versus contact time for Tests $1-5\left(25^{\circ} \mathrm{C}, 5.6 \mathrm{M} \mathrm{Na}\right)$.................... 6

Figure 3-4. ${ }^{237} \mathrm{~Np}$ concentration versus contact time for Tests $1-5\left(25^{\circ} \mathrm{C}, 5.6 \mathrm{M} \mathrm{Na}\right) \ldots \ldots \ldots \ldots \ldots \ldots . . . . . .6$

Figure 3-5. U concentration versus contact time for Tests $1-5\left(25^{\circ} \mathrm{C}, 5.6 \mathrm{M} \mathrm{Na}\right)$...................... 7

Figure 3-6. ${ }^{85} \mathrm{Sr}$ DF versus contact time with MST in various ionic strength solutions. The data points represent the average of duplicate trials, and the error bars are the standard deviations of those averages.

Figure 3-7. ${ }^{85} \mathrm{Sr}$ DF versus contact time with mMST in various ionic strength solutions. The data points represent the average of duplicate trials, and the error bars are the standard deviations of those averages.

Figure 3-8. Pu DF versus contact time with MST in various ionic strength solutions. The data points represent the average of duplicate trials, and the error bars are the standard deviations of those averages. 11

Figure 3-9. Pu DF versus contact time with mMST in various ionic strength solutions. The data points represent the average of duplicate trials, and the error bars are the standard deviations of those averages. 11

Figure 3-10. Np DF versus contact time with MST in various ionic strength solutions. The data points represent the average of duplicate trials, and the error bars are the standard deviations of those averages.

Figure 3-11. Np DF versus contact time with mMST in various ionic strength solutions. The data points represent the average of duplicate trials, and the error bars are the standard deviations of those averages.

Figure 3-12. ${ }^{85} \mathrm{Sr}$ DF versus contact time with MST at various temperatures. The data points represent the average of duplicate trials, and the error bars are the standard deviations of those averages. 14 
Figure 3-13. ${ }^{85} \mathrm{Sr}$ DF versus contact time with mMST at various temperatures. The data points represent the average of duplicate trials, and the error bars are the standard deviations of those averages.

Figure 3-14. Pu DF versus contact time with MST at various temperatures. The data points represent the average of duplicate trials, and the error bars are the standard deviations of those averages.

Figure 3-15. Pu DF versus contact time with mMST at various temperatures. The data points represent the average of duplicate trials, and the error bars are the standard deviations of those averages.

Figure 3-16. Np DF versus contact time with MST at various temperatures. The data points represent the average of duplicate trials, and the error bars are the standard deviations of those averages.

Figure 3-17. Np DF versus contact time with mMST at various temperatures. The data points represent the average of duplicate trials, and the error bars are the standard deviations of those averages. 16

Figure A-1. ${ }^{226} \mathrm{Ra}$ DF versus contact time for Tests $2-5\left(25{ }^{\circ} \mathrm{C}, 5.6 \mathrm{M} \mathrm{Na}\right)$. Open data points

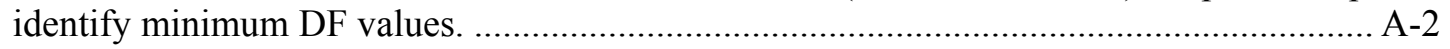

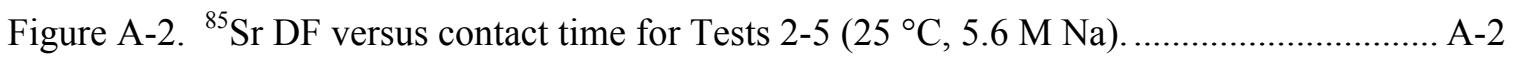

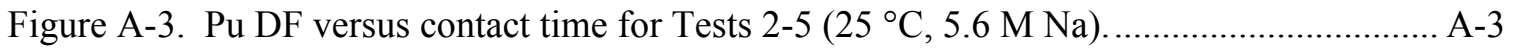

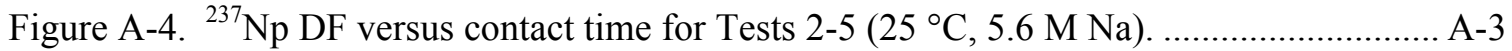

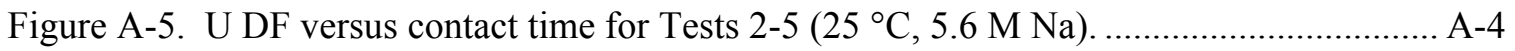

Figure A-6. ${ }^{85} \mathrm{Sr}$ and ${ }^{226} \mathrm{Ra}$ activity in control samples from Tests $1-5\left(25^{\circ} \mathrm{C}\right), 16-20\left(45^{\circ} \mathrm{C}\right)$, and $21-25\left(60{ }^{\circ} \mathrm{C}\right)$. A-6

Figure A-7. Np and Pu concentrations in control samples from Tests 1-5 $\left(25^{\circ} \mathrm{C}\right), 16-20\left(45^{\circ} \mathrm{C}\right)$, and $21-25\left(60^{\circ} \mathrm{C}\right)$. A-6 


\section{LIST OF ABBREVIATIONS}

$\begin{array}{ll}\text { ALARA } & \text { as low as reasonably achievable } \\ \text { ARP } & \text { Actinide Removal Process } \\ \text { DF } & \text { decontamination factor } \\ \text { DSS } & \text { decontaminated salt solution } \\ \text { HLW } & \text { High-Level Waste } \\ \text { ICP-ES } & \text { inductively coupled plasma - emission spectroscopy } \\ \text { ICP-MS } & \text { inductively coupled plasma - mass spectroscopy } \\ \text { MCU } & \text { Modular Caustic-Side Solvent Extraction Processing Unit } \\ \text { MDL } & \text { method detection limit } \\ \text { MST } & \text { monosodium titanate } \\ \text { mMST } & \text { modified monosodium titanate } \\ \text { PA } & \text { Performance Assessment } \\ \text { PuTTA } & \text { plutonium thenoyltrifluoroacetone scintillation } \\ \text { PVDF } & \text { polyvinylidene fluoride } \\ \text { SCIX } & \text { small column ion exchange } \\ \text { SPF } & \text { Saltstone Production Facility } \\ \text { SRNL } & \text { Savannah River National Laboratory } \\ \text { SRR } & \text { Savannah River Remediation } \\ \text { SRS } & \text { Savannah River Site } \\ \text { SWPF } & \text { Salt Waste Processing Facility } \\ \text { TTQAP } & \text { Task Technical and Quality Assurance Plan } \\ \end{array}$




\subsection{Introduction}

The Saltstone Facility in Z-Area processes and disposes of decontaminated salt solution (DSS) from the tank farm. The salt solution consists of low-level mixed waste primarily from the Effluent Treatment Project, Low Curie Salt, Actinide Removal Project (ARP), Modular CausticSide Solvent Extraction Processing Unit (MCU), and the future Salt Waste Processing Facility (SWPF). The Z-Area Saltstone Production Facility (SPF) immobilizes the radioactive solution into a cement product referred to as Saltstone, which is suitable for safe disposal in near surface vaults. The current ARP, future SWPF, and Small Column Ion Exchange (SCIX) process each use MST to sorb soluble strontium and actinides and produce a DSS stream, which is eventually sent to the SPF after the radioactive cesium is removed in a separate process. The SPF Performance Assessment (PA) assumes a specific radionuclide concentration based on monosodium titanate (MST) sorption data. To confirm PA inputs, additional testing on MST and modified MST (mMST) sorption was required. Specifically, testing was required to examine the radium and thorium removal by MST and mMST under various conditions, including a range of ionic strengths and temperatures. In addition to the sorption testing, a series of tests were also performed to examine desorption of sorbates under simulated washing conditions. Conditions tested represented the intermediate and final stages of washing. This work was performed at the request of Savannah River Remediation (SRR) Engineering ${ }^{1}$ and was controlled by a Task Technical and Quality Assurance Plan (TTQAP). ${ }^{2}$

\subsection{Experimental Procedure}

\subsection{Sources of MST and mMST}

The baseline MST used in these studies was prepared using a sol-gel process developed at the Savannah River National Laboratory (SRNL) and supplied by Optima Chemical Group LLC (Douglas, GA, Lot \#00-QAB-417) as a $15 \mathrm{wt} \%$ suspension in water containing $0.10-0.15 \mathrm{M}$ $\mathrm{NaOH}$ and $100-150 \mathrm{mg} \mathrm{L}^{-1} \mathrm{NaNO}_{2}{ }^{3}{ }^{3}$ mMST used in these studies was prepared by the postsynthesis treatment of MST with hydrogen peroxide. The details of this procedure have been previously published. ${ }^{4}$ A bench-scale quantity of the mMST (LS-11) was prepared using 25 grams of the Optima-supplied MST.

\subsection{Simulant Preparation}

The chemical composition of the simulants used in this testing is based upon the simulant developed for solvent extraction testing, with some simplifications. ${ }^{5}$ The concentrations of the salts were then varied slightly to produce the higher and lower ionic strength simulants. Trace salts were omitted as their presence was previously shown not to effect the sorption properties of MST. ${ }^{6}$ The actinide concentrations are consistent with the simulant used for previous MST testing. The $\mathrm{Pu}$ concentration of $0.2 \mathrm{mg} / \mathrm{L}$ bounds the $\mathrm{Pu}$ concentration in 6 out of 7 of the tanks selected as bounding for the SWPF (i.e., Tanks $13 \mathrm{H}, 30 \mathrm{H}, 37 \mathrm{H}, 39 \mathrm{H}, 45 \mathrm{~F}, 46 \mathrm{~F}$, and $49 \mathrm{H}$ ). ${ }^{7}$ Tank $39 \mathrm{H}$ had a measured soluble $\mathrm{Pu}$ content of $1.13 \mathrm{mg} / \mathrm{L}$; however, the next highest measured $\mathrm{Pu}$ concentration was $0.0081 \mathrm{mg} / \mathrm{L}$ (Tank $37 \mathrm{H}$ ). The $U$ and $N p$ concentrations of 10 and $0.5 \mathrm{mg} / \mathrm{L}$, respectively, bound all 7 of the previously mentioned tanks. The total $\mathrm{Sr}$ concentration is based upon the average $\mathrm{Sr}$ concentration measured in the 7 tanks. The target $\mathrm{Sr}$ concentration is 6 $\mathrm{mg} / \mathrm{L}$; however, this concentration may not be achieved due to the elevated carbonate concentration in this simulant. We selected a target concentration of thorium of $2.0 \mathrm{mg} / \mathrm{L}$ to ensure that the simulant was saturated with Th(IV) and ${ }^{228} \mathrm{Th}$ was also added as a radiotracer for determination of decontamination factors (DFs) by gamma counting. However, due to the very low solubility of Th(IV) in alkaline solutions, no soluble thorium was detected in the prepared

simulants. There are no stable isotopes of radium and availability and ALARA considerations 
limited the addition of radium isotopes to tracer levels versus the estimated solubility limit of radium. Thus, for this testing ${ }^{226} \mathrm{Ra}$ was added at a target activity level of $4000 \mathrm{dpm} / \mathrm{mL}(1.80$ $\mu \mathrm{g} / \mathrm{L}$ ). The simulants were filtered before use to remove insoluble species and the soluble concentrations of all components were measured. The compositions of the simulants are provided in Table $2-1$.

Table 2-1. Compositions of Simulants.

\begin{tabular}{|c|c|c|c|c|c|c|}
\hline \multirow[b]{2}{*}{ Component } & \multicolumn{2}{|c|}{ SWS-7-2011-4.6 } & \multicolumn{2}{|c|}{ SWS-7-2011-5.6 } & \multicolumn{2}{|c|}{ SWS-7-2011-6.6 } \\
\hline & $\begin{array}{c}\text { Target } \\
\text { Concentration }\end{array}$ & $\begin{array}{c}\text { Measured } \\
\text { Concentration }\end{array}$ & $\begin{array}{c}\text { Target } \\
\text { Concentration }\end{array}$ & $\begin{array}{c}\text { Measured } \\
\text { Concentration }\end{array}$ & $\begin{array}{c}\text { Target } \\
\text { Concentration }\end{array}$ & $\begin{array}{c}\text { Measured } \\
\text { Concentration }\end{array}$ \\
\hline Free $\mathrm{NaOH}$ & $1.82 \mathrm{M}$ & $1.58 \pm 0.16 \mathrm{M}$ & $2.21 \mathrm{M}$ & $2.07 \pm 0.21 \mathrm{M}$ & $2.60 \mathrm{M}$ & $2.35 \pm 0.24 \mathrm{M}$ \\
\hline $\mathrm{NaNO}_{3}$ & $1.67 \mathrm{M}$ & $1.76 \pm 0.18 \mathrm{M}$ & $2.03 \mathrm{M}$ & $2.06 \pm 0.21 \mathrm{M}$ & $2.39 \mathrm{M}$ & $2.39 \pm 0.24 \mathrm{M}$ \\
\hline $\mathrm{NaAl}(\mathrm{OH})_{4}$ & $0.230 \mathrm{M}$ & $0.215 \pm 0.022 \mathrm{M}$ & $0.280 \mathrm{M}$ & $0.271 \pm 0.027 \mathrm{M}$ & $0.330 \mathrm{M}$ & $0.312 \pm 0.031 \mathrm{M}$ \\
\hline $\mathrm{NaNO}_{2}$ & $0.411 \mathrm{M}$ & $0.419 \pm 0.042 \mathrm{M}$ & $0.500 \mathrm{M}$ & $0.506 \pm 0.051 \mathrm{M}$ & $0.589 \mathrm{M}$ & $0.550 \pm 0.055 \mathrm{M}$ \\
\hline $\mathrm{Na}_{2} \mathrm{SO}_{4}$ & $0.115 \mathrm{M}$ & $0.095 \pm 0.010 \mathrm{M}$ & $0.140 \mathrm{M}$ & $0.144 \pm 0.014 \mathrm{M}$ & $0.165 \mathrm{M}$ & $0.134 \pm 0.013 \mathrm{M}$ \\
\hline $\mathrm{Na}_{2} \mathrm{CO}_{3}$ & $0.123 \mathrm{M}$ & $0.137 \pm 0.014 \mathrm{M}$ & $0.150 \mathrm{M}$ & $0.164 \pm 0.016 \mathrm{M}$ & $0.177 \mathrm{M}$ & $0.191 \pm 0.019 \mathrm{M}$ \\
\hline Total $\mathrm{Na}$ & $4.6 \mathrm{M}$ & $4.39 \pm 0.44 \mathrm{M}$ & $5.6 \mathrm{M}$ & $5.48 \pm 0.55 \mathrm{M}$ & $6.6 \mathrm{M}$ & $6.35 \pm 0.64 \mathrm{M}$ \\
\hline${ }^{85} \mathrm{Sr}$ & $30,000 \mathrm{dpm} / \mathrm{mL}$ & $\begin{array}{c}14,000 \pm 700 \\
\mathrm{dpm} / \mathrm{mL}\end{array}$ & $\begin{array}{r}30,000 \\
\mathrm{dpm} / \mathrm{mL}\end{array}$ & $\begin{array}{c}13,200 \pm 660 \\
\mathrm{dpm} / \mathrm{mL}\end{array}$ & $\begin{array}{r}30,000 \\
\mathrm{dpm} / \mathrm{mL}\end{array}$ & $\begin{array}{c}18,000 \pm 900 \\
\mathrm{dpm} / \mathrm{mL}\end{array}$ \\
\hline${ }^{226} \mathrm{Ra}$ & $4,000 \mathrm{dpm} / \mathrm{mL}$ & $\begin{array}{c}3,870 \pm 194 \\
\mathrm{dpm} / \mathrm{mL}\end{array}$ & $4,000 \mathrm{dpm} / \mathrm{mL}$ & $\begin{array}{c}4,130 \pm 207 \\
\mathrm{dpm} / \mathrm{mL}\end{array}$ & $4,000 \mathrm{dpm} / \mathrm{mL}$ & $\begin{array}{c}4,080 \pm 204 \\
\mathrm{dpm} / \mathrm{mL}\end{array}$ \\
\hline${ }^{228} \mathrm{Th}$ & $4,000 \mathrm{dpm} / \mathrm{mL}$ & $<262 \mathrm{dpm} / \mathrm{mL}$ & $4,000 \mathrm{dpm} / \mathrm{mL}$ & $<262 \mathrm{dpm} / \mathrm{mL}$ & $4,000 \mathrm{dpm} / \mathrm{mL}$ & $<262 \mathrm{dpm} / \mathrm{mL}$ \\
\hline Total Sr & $6.0 \mathrm{mg} / \mathrm{L}$ & $1.06 \pm 0.21 \mathrm{mg} / \mathrm{L}$ & $6.0 \mathrm{mg} / \mathrm{L}$ & $0.909 \pm 0.182 \mathrm{mg} / \mathrm{L}$ & $6.0 \mathrm{mg} / \mathrm{L}$ & $1.48 \pm 0.30 \mathrm{mg} / \mathrm{L}$ \\
\hline Total Cs & $18.6 \mathrm{mg} / \mathrm{L}$ & $16.2 \pm 3.2 \mathrm{mg} / \mathrm{L}$ & $18.6 \mathrm{mg} / \mathrm{L}$ & $17.5 \pm 3.5 \mathrm{mg} / \mathrm{L}$ & $18.6 \mathrm{mg} / \mathrm{L}$ & $17.3 \pm 3.5 \mathrm{mg} / \mathrm{L}$ \\
\hline Th & $2,000 \mu \mathrm{g} / \mathrm{L}$ & $<50 \mu \mathrm{g} / \mathrm{L}$ & $2,000 \mu \mathrm{g} / \mathrm{L}$ & $<50 \mu \mathrm{g} / \mathrm{L}$ & $2,000 \mu \mathrm{g} / \mathrm{L}$ & $<50 \mu \mathrm{g} / \mathrm{L}$ \\
\hline Total $\mathrm{Pu}$ & $200 \mu \mathrm{g} / \mathrm{L}$ & $199 \pm 9.95 \mu \mathrm{g} / \mathrm{L}$ & $200 \mu \mathrm{g} / \mathrm{L}$ & $168 \pm 8.4 \mu \mathrm{g} / \mathrm{L}$ & $200 \mu \mathrm{g} / \mathrm{L}$ & $178 \pm 8.9 \mu \mathrm{g} / \mathrm{L}$ \\
\hline $\mathrm{Np}$ & $500 \mu \mathrm{g} / \mathrm{L}$ & $443 \pm 88.6 \mu \mathrm{g} / \mathrm{L}$ & $500 \mu \mathrm{g} / \mathrm{L}$ & $486 \pm 97.2 \mu \mathrm{g} / \mathrm{L}$ & $500 \mu \mathrm{g} / \mathrm{L}$ & $484 \pm 96.8 \mu \mathrm{g} / \mathrm{L}$ \\
\hline $\mathrm{U}$ & $10,000 \mu \mathrm{g} / \mathrm{L}$ & $\begin{array}{c}11,200 \pm 2,240 \\
\mu \mathrm{g} / \mathrm{L}\end{array}$ & $10,000 \mu \mathrm{g} / \mathrm{L}$ & $\begin{array}{c}11,100 \pm 2,220 \\
\mu \mathrm{g} / \mathrm{L}\end{array}$ & $10,000 \mu \mathrm{g} / \mathrm{L}$ & $\begin{array}{c}10,800 \pm 2,160 \\
\mu \mathrm{g} / \mathrm{L}\end{array}$ \\
\hline
\end{tabular}

\section{$2.3 \underline{\text { Sorption Tests }}$}

A total of 25 individual sorption tests were performed. Tests 1-5 were performed using simulant SWS-7-2011-5.6 at $25{ }^{\circ} \mathrm{C}$. For these tests $120 \mathrm{~mL}$ of simulant was added to each of three 250mL polyethylene bottles: RaThMST-1 (control, no sorbent), RaThMST-2 and RaThMST-3 (MST - duplicate tests), and RaThMST-4 and RaThMST-5 (mMST - duplicate tests). The control bottle was sampled at each sampling event to monitor for any changes in sorbate concentration due to precipitation or sorption by the polyethylene bottle. MST and mMST were added to the remaining bottles at concentrations of $0.4 \mathrm{~g} / \mathrm{L}$ and $0.2 \mathrm{~g} / \mathrm{L}$, respectively. After adding the sorbents, the bottles were placed in a shaker-oven, maintained at an average temperature of $27.0 \pm$ $0.73{ }^{\circ} \mathrm{C}$, and were continually shaken at $175 \mathrm{rpm}$. Samples were removed at times of $0.5,1,2,4$, $6,12,24,168$, and 336 hours. At each sampling event, the bottle was removed from the oven and manually shaken for 30 seconds to ensure the solids were homogeneously suspended. A sample was then removed and filtered through a $0.1-\mu \mathrm{m}$ polyvinylidene fluoride (PVDF) syringe filter to remove the solids. An aliquot of the filtrate was acidified with an equal volume of $5 \mathrm{M}$ nitric acid and submitted for inductively coupled plasma - mass spectroscopy (ICP-MS), gamma scan, and plutonium thenoyltrifluoroacetone scintillation (PuTTA) analyses.

Similar procedures were used for the remaining tests. For Tests $6-10,60 \mathrm{~mL}$ of simulant SWS-72011-4.6 was added to each of five 125-mL polyethylene bottles: RaThMST-6 (control, no sorbent), RaThMST-7 and RaThMST-8 (MST - duplicate tests), and RaThMST-9 and RaThMST-10 (mMST - duplicate tests). For Tests 11-15, $60 \mathrm{~mL}$ of simulant SWS-7-2011-6.6 was added to each of five $125-\mathrm{mL}$ polyethylene bottles: RaThMST-11 (control, no sorbent), RaThMST-12 and RaThMST-13 (MST - duplicate tests), and RaThMST-14 and RaThMST-15 
(mMST - duplicate tests). The MST and mMST were added at concentrations of $0.4 \mathrm{~g} / \mathrm{L}$ and 0.2 $\mathrm{g} / \mathrm{L}$, respectively. After adding the sorbents, the bottles were placed in a shaker-oven, maintained at an average temperature of $25.3 \pm 0.07{ }^{\circ} \mathrm{C}$, and were continually shaken at $175 \mathrm{rpm}$. Samples were removed at times of $6,12,24$, and 336 hours. The same sampling procedure described for Tests 1-5 was also used for these tests.

For Tests 16-25, $60 \mathrm{~mL}$ of simulant SWS-5-2011-5.6 was used for each test. Each set of tests (16-20 and 21-25) contained 1 control bottle, 2 MST bottles, and 2 mMST bottles. Tests 16-20 were carried out in a shaker oven with an average temperature of $46.4 \pm 1.05{ }^{\circ} \mathrm{C}$, and Tests $21-25$ in a shaker oven with an average temperature of $60.3 \pm 1.30^{\circ} \mathrm{C}$. Samples were removed after 6 , 12, and 24 hours using the sampling procedure described above for Tests 1-5.

\subsection{Desorption Tests}

\subsubsection{Loading of MST and mMST}

Samples of MST and mMST were loaded with sorbates by contacting with SWS-7-2011-5.6 for a period of two weeks. Specifically, $3.835 \mathrm{~g}$ of a $14.60 \mathrm{wt} \%$ suspension of MST (Optima, Lot \# 00-QAB-417) was added to 1.4 L of SWS-7-2011-5.6, giving a final MST concentration of 0.4 $\mathrm{g} / \mathrm{L}$. For the mMST loading, $3.607 \mathrm{~g}$ of a $15.53 \mathrm{wt} \%$ suspension of mMST (LS-11) was added to 1.4 L of SWS-7-2011-5.6, giving a final mMST concentration of $0.4 \mathrm{~g} / \mathrm{L}$. The mixtures were stirred at ambient temperature for two weeks. The loaded solids $(0.56 \mathrm{~g}$ of each $)$ were then collected by filtering through a $0.45-\mu \mathrm{m}$ disposable filter. The solids were transferred from the filter using a small amount of the filtrate, and were diluted to a total volume of $4 \mathrm{~mL}$ with additional filtrate, giving an MST or mMST suspension with a final concentration of $0.14 \mathrm{~g} / \mathrm{mL}$, assuming no loss of the solids. The DSSs were then diluted for the desorption experiments as described below.

\subsubsection{Desorption Test}

Desorption tests were carried out by contacting samples of the loaded MST and mMST with diluted DSSs having sodium concentrations of $2 \mathrm{M}$ and $0.5 \mathrm{M}$. These concentrations were selected to represent the intermediate and final stages of washing. Specifically, $0.9 \mathrm{~mL}$ of the loaded MST or mMST suspension $(0.14 \mathrm{~g} / \mathrm{mL})$ was placed into one of 8 test bottles (4 for MST and 4 for mMST). Aliquots of distilled water and DSS were then added to each bottle in the ratio needed to provide a sodium concentration of either $2 \mathrm{M}$ or $0.5 \mathrm{M}$. The total volume of each test bottle was $10 \mathrm{~mL}$, and the MST or mMST concentration was $12.7 \mathrm{~g} / \mathrm{L}$, or $1 \mathrm{wt} \%$. The bottles were then placed in a shaker oven, maintained at an average temperature of $25.7 \pm 0.43{ }^{\circ} \mathrm{C}$, and were continually shaken at $175 \mathrm{rpm}$. For both MST and mMST, two bottles were prepared for each sodium concentration. One set of bottles was sampled after 24 hours, and the other was sampled after 336 hours. At each sampling event, the bottle was removed from the oven and manually shaken for 30 seconds to ensure the solids were homogeneously suspended. The contents of the bottle were then filtered through a 0.1- $\mu \mathrm{m}$ PVDF syringe filter to remove the solids. An aliquot of the filtrate was acidified with an equal volume of $5 \mathrm{M}$ nitric acid and submitted for ICP-MS, gamma scan, and PuTTA analyses. An aliquot of the filtrate prior to acidification was also submitted for inductively coupled plasma - emission spectroscopy (ICPES) analysis. Control samples of the DSS diluted to $2 \mathrm{M}$ and $0.5 \mathrm{M} \mathrm{Na}$ were also submitted for analysis to determine the starting concentrations before desorption. 


\subsection{Results and Discussion}

\subsection{Thorium and Radium Solubility}

Isotopes of thorium and radium are not fission products of uranium or plutonium, but would be produced as daughter products from the radioactive decay of uranium. The most stable oxidation states of thorium and radium in aqueous solutions are $\mathrm{Th}(\mathrm{IV})$ and $\mathrm{Ra}(\mathrm{II})$. The solubility of thorium as Th(IV) in water is reported to be very low $(7.3 \mathrm{E}-07 \mathrm{~g} / \mathrm{L}$ or $3.1 \mathrm{E}-09 \mathrm{M})$ and constant over the $\mathrm{pH}$ range of 7 to $13 .{ }^{8}$ Thus, the expected solubility of Th(IV) in the strongly alkaline and high ionic strength Savannah River Site (SRS) high-level waste (HLW) solutions is expected to be quite low.

No published accounts of the solubility of $\mathrm{Ra}$ (II) under alkaline conditions could be located. However, since radium is an alkaline earth element, the solubility would be expected to be similar to that of strontium. Concentrations of strontium in HLW supernate samples range from about 0.1 to $10 \mathrm{mg} / \mathrm{L}$. Even though the solubility of radium may be as high as $10 \mathrm{mg} / \mathrm{L}$, the total quantity of radium in SRS HLW would be expected to be extremely low given the decay path for producing radium isotopes.

Radiochemical analyses have not detected thorium or radium in any tank supernate samples confirming the expected low concentrations in HLW supernates. ${ }^{7}$ For this testing, we selected a target concentration of natural abundance thorium of $2.0 \mathrm{mg} / \mathrm{L}$ to ensure that the simulant was saturated with $\mathrm{Th}(\mathrm{IV}) .{ }^{228} \mathrm{Th}$ was also added as a radiotracer for determination of DFs by gamma counting. However, due to the very low solubility of Th(IV) in alkaline solutions, no soluble thorium was detected in any of the prepared simulants. Based on the reported detection limits for ${ }^{228} \mathrm{Th}$ by gamma analysis, the solubility of Th in the simulant solutions is $<3.0 \mathrm{E}-10 \mathrm{~g} / \mathrm{L}$ or $<$ $1.3 \mathrm{E}-12 \mathrm{M}$. This low concentration is not unexpected due to the high ionic strength of the simulant, and the reported low solubility of Th in solutions with much lower ionic strengths.

There are no stable isotopes of radium. Availability and as low as reasonably achievable (ALARA) considerations limited the addition of radium isotopes to tracer levels versus the estimated solubility limit of radium. Thus, for this testing ${ }^{226} \mathrm{Ra}$ was added at a target activity level of $4000 \mathrm{dpm} / \mathrm{mL}(1.80 \mu \mathrm{g} / \mathrm{L})$ in all of the simulants.

\subsection{Comparison of MST and mMST Sorption Performance}

Figures 3-1 through 3-5 show the ${ }^{226} \mathrm{Ra},{ }^{85} \mathrm{Sr}$, and actinide concentrations as a function of time for the sorption tests performed under the standard conditions (i.e., $25^{\circ} \mathrm{C}$ and $5.6 \mathrm{M} \mathrm{Na}$ simulant SWS-7-2011-5.6). The DFs are summarized in Tables 3-1 through 3-5, and the plots of DF versus time are provided in the Appendix. Results from the control samples indicated no change in sorbate concentrations over the course of the experiment.

The sorption of ${ }^{226} \mathrm{Ra}$ was found to be very rapid with both MST and mMST, and the rate of removal appears to behave like that of $\mathrm{Sr}$ and not like that of the actinides. The ${ }^{226} \mathrm{Ra}$ activity fell below the MDL within 30 minutes of contact with MST, whereas the first data point to be below the detection limit for the mMST tests was at 2 hours (Table 3-1). The performance of MST and mMST in the removal of the $\mathrm{Sr}$ and actinides in this test set is consistent with that measured in prior testing. ${ }^{9} \quad$ mMST removes ${ }^{85} \mathrm{Sr}$ and Pu more rapidly and to a greater extent (at these time scales) than MST. The Np removal by MST and mMST is similar through 24 hours of contact; however, MST reaches slightly higher DFs at the later time points. Uranium removal by MST is greater than that by mMST which, as has been shown in previous testing, has little affinity for uranium under these highly alkaline conditions. 
SRNL-STI-2012-00072

Revision 0

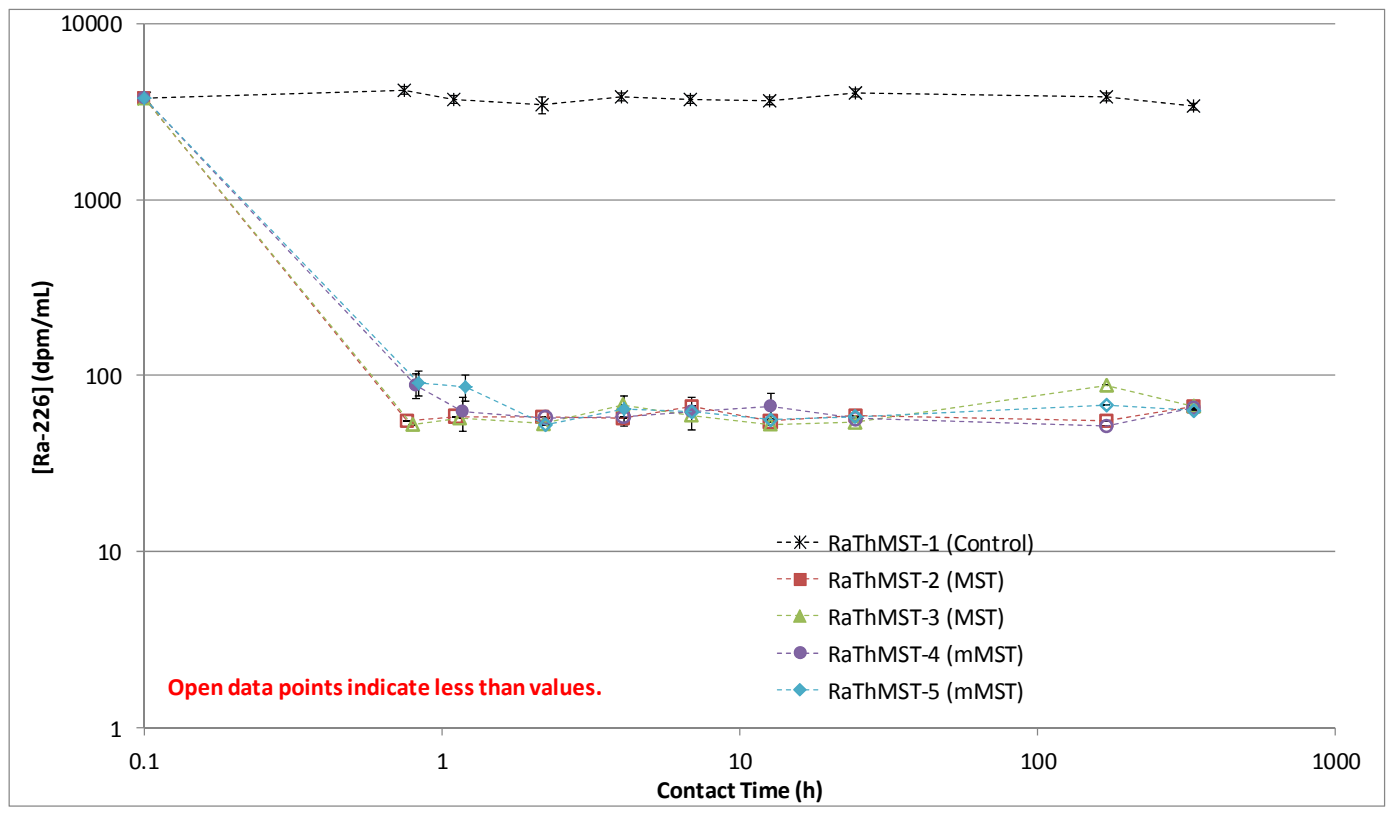

Figure 3-1. ${ }^{226}$ Ra activity versus contact time for Tests $1-5\left(25^{\circ} \mathrm{C}, 5.6 \mathrm{M} \mathrm{Na}\right)$. Open data points identify maximum concentrations (i.e., measured concentrations are at detection limits).

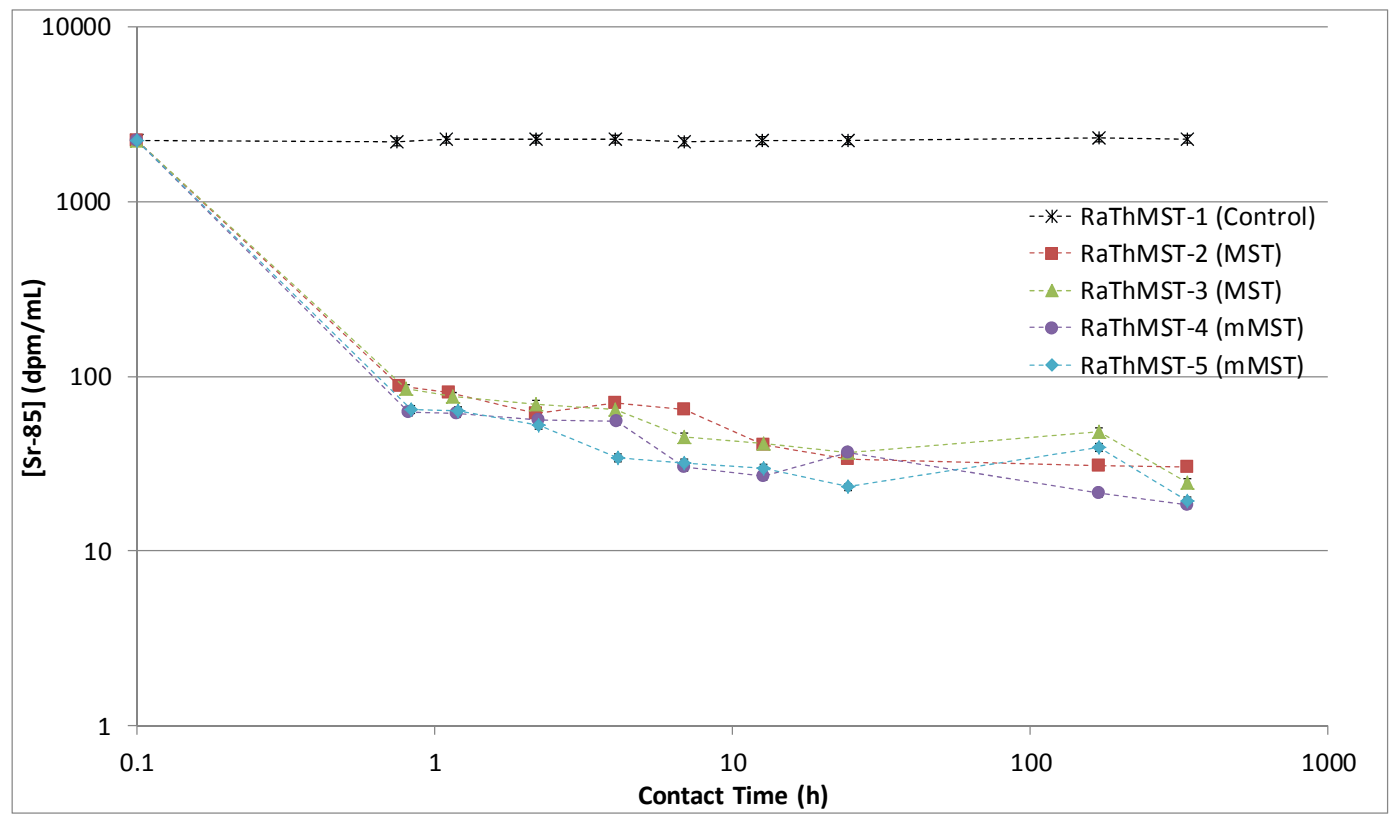

Figure 3-2. ${ }^{85} \mathrm{Sr}$ activity versus contact time for Tests $1-5\left(25^{\circ} \mathrm{C}, 5.6 \mathrm{M} \mathrm{Na}\right)$. 
SRNL-STI-2012-00072

Revision 0

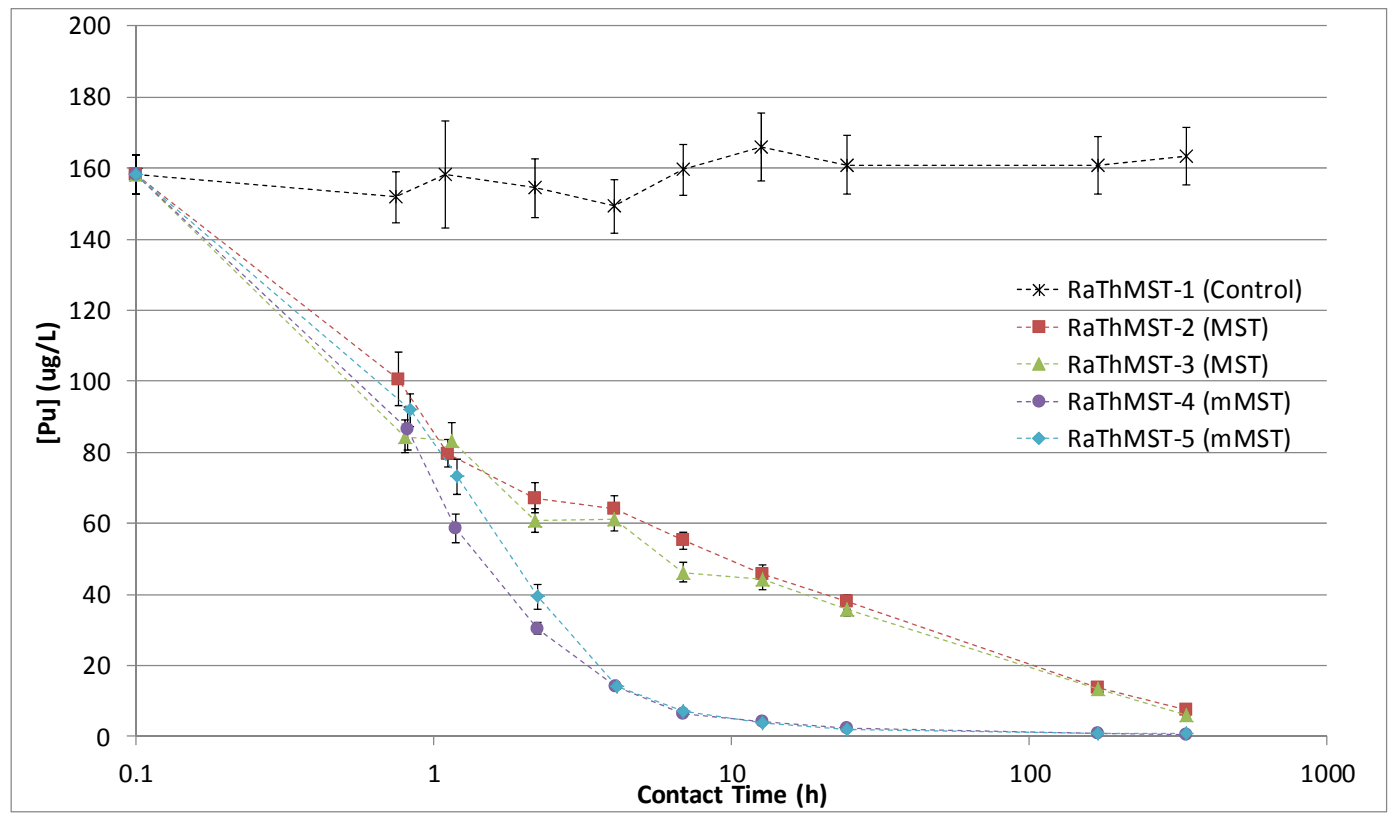

Figure 3-3. Pu concentration versus contact time for Tests $1-5\left(25^{\circ} \mathrm{C}, 5.6 \mathrm{M} \mathrm{Na}\right)$.

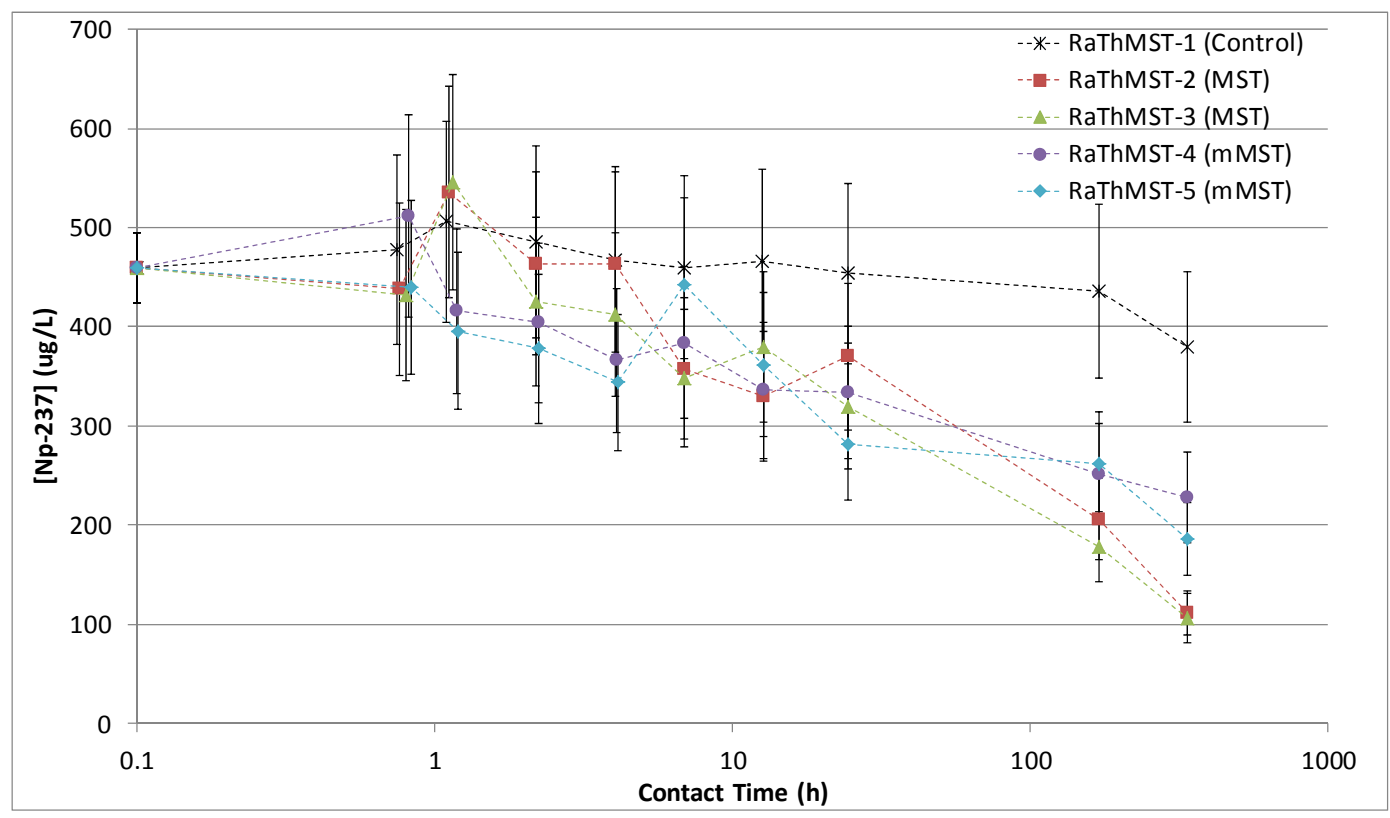

Figure 3-4. ${ }^{237} \mathrm{~Np}$ concentration versus contact time for Tests $1-5\left(25^{\circ} \mathrm{C}, 5.6 \mathrm{M} \mathrm{Na}\right)$. 


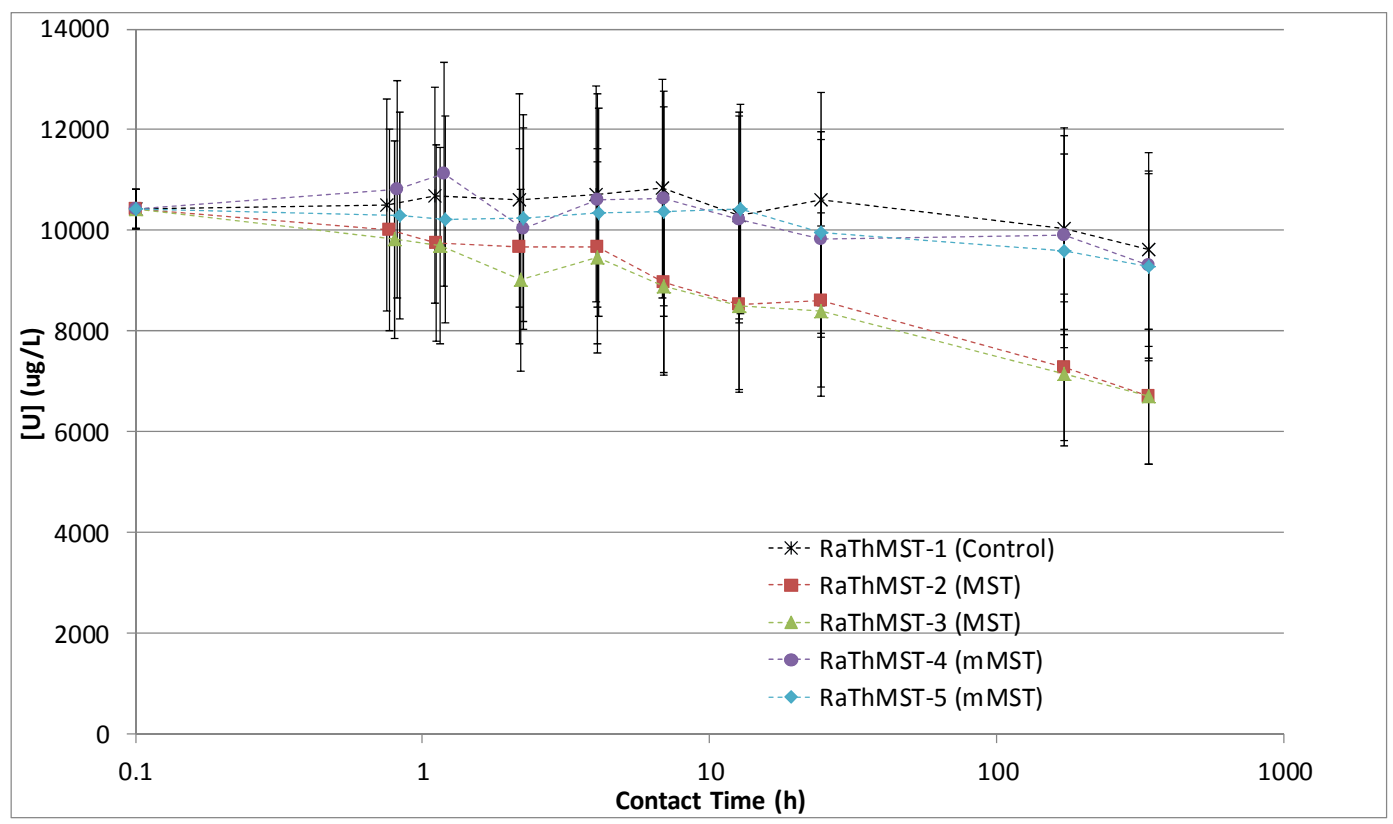

Figure 3-5. $\mathrm{U}$ concentration versus contact time for Tests $1-5\left(25^{\circ} \mathrm{C}, 5.6 \mathrm{M} \mathrm{Na}\right)$.

Table 3-1. Summary of ${ }^{226}$ Ra DFs obtained at $25^{\circ} \mathrm{C}$ after contact with SWS-7-2011-5.6. The numbers in parenthesis represent one sigma uncertainty. Many of the measured values fell below the MDL, resulting in greater than values being obtained for the DFs.

\begin{tabular}{|c|c|c|c|c|c|c||}
\hline \multirow{2}{*}{$\begin{array}{c}\text { Time } \\
\text { (h) }\end{array}$} & \multicolumn{7}{|c|}{$\begin{array}{c}{ }^{226} \text { Ra DFs } \\
\text { (MST) }\end{array}$} & $\begin{array}{c}\text { RaThMST-3 } \\
\text { (MST) }\end{array}$ & Ave. MST & $\begin{array}{c}\text { RaThMST-4 } \\
\text { (mMST) }\end{array}$ & $\begin{array}{c}\text { RaThMST-5 } \\
\text { (mMST) }\end{array}$ & Ave. mMST \\
\hline $\mathbf{0 . 5}$ & $>75.5$ & $>79.5$ & $>77.5$ & $47.7(8.13)$ & $46.1(7.80)$ & $46.9(1.18)$ \\
\hline $\mathbf{1}$ & $>63.3$ & $>64.8$ & $>64.0$ & $60.0(13.6)$ & $43.2(7.63)$ & $51.6(11.9)$ \\
\hline $\mathbf{2}$ & $>59.1$ & $>64.7$ & $>61.9$ & $>59.5$ & $>65.4$ & $>62.5$ \\
\hline $\mathbf{4}$ & $>67.5$ & $>56.3$ & $>61.9$ & $>65.9$ & $59.9(12.1)$ & $>62.9$ \\
\hline $\mathbf{6}$ & $>55.7$ & $>62.4$ & $>59.1$ & $59.8(12.7)$ & $>59.8$ & $>59.8$ \\
\hline $\mathbf{1 2}$ & $>66.2$ & $>68.7$ & $>67.4$ & $54.2(10.6)$ & $>65.0$ & $>59.6$ \\
\hline $\mathbf{2 4}$ & $>68.4$ & $>74.9$ & $>71.6$ & $>71.2$ & $>69.3$ & $>70.3$ \\
\hline $\mathbf{1 6 8}$ & $>68.7$ & $>43.3$ & $>56.0$ & $>73.7$ & $>56.2$ & $>65.0$ \\
\hline $\mathbf{3 3 6}$ & $>50.3$ & $>50.3$ & $>50.3$ & $>51.4$ & $>53.5$ & $>52.4$ \\
\hline \hline
\end{tabular}


Table 3-2. Summary of ${ }^{85} \mathrm{Sr}$ DFs obtained at $25{ }^{\circ} \mathrm{C}$ after contact with SWS-7-2011-5.6. The numbers in parenthesis represent one sigma uncertainty.

\begin{tabular}{|c|c|c|c|c|c|c||}
\hline \multirow{2}{*}{$\begin{array}{c}\text { Time } \\
\text { (h) }\end{array}$} & $\begin{array}{c}\text { RaThMST-2 } \\
\text { (MST) }\end{array}$ & $\begin{array}{c}\text { RaThMST-3 } \\
\text { (MST) }\end{array}$ & Ave. MST & $\begin{array}{c}\text { RaThMST-4 } \\
\text { (mMST) }\end{array}$ & $\begin{array}{c}\text { RaThMST-5 } \\
\text { (mMST) }\end{array}$ & Ave. mMST \\
\hline $\mathbf{0 . 5}$ & $24.9(1.76)$ & $26.0(1.84)$ & $25.4(0.80)$ & $35.1(2.48)$ & $34.0(2.41)$ & $34.6(0.78)$ \\
\hline $\mathbf{1}$ & $27.8(1.97)$ & $29.4(2.08)$ & $28.6(1.14)$ & $36.9(2.61)$ & $35.8(2.53)$ & $36.4(0.74)$ \\
\hline $\mathbf{2}$ & $37.6(2.66)$ & $33.3(2.35)$ & $35.5(3.06)$ & $40.7(2.87)$ & $43.5(3.08)$ & $42.1(2.01)$ \\
\hline $\mathbf{4}$ & $32.8(2.32)$ & $35.9(2.54)$ & $34.3(2.17)$ & $41.4(2.93)$ & $67.1(4.74)$ & $54.2(18.1)$ \\
\hline $\mathbf{6}$ & $34.3(2.42)$ & $49.0(3.46)$ & $41.6(10.4)$ & $73.4(5.19)$ & $69.8(4.94)$ & $71.6(2.49)$ \\
\hline $\mathbf{1 2}$ & $55.9(3.95)$ & $54.9(3.88)$ & $55.4(0.70)$ & $84.1(5.95)$ & $75.9(5.37)$ & $80.0(5.77)$ \\
\hline $\mathbf{2 4}$ & $66.7(4.72)$ & $61.1(4.32)$ & $63.9(3.98)$ & $61.0(4.31)$ & $96.9(6.85)$ & $79.0(25.4)$ \\
\hline $\mathbf{1 6 8}$ & $75.1(5.31)$ & $47.8(3.38)$ & $61.5(19.4)$ & $107(7.58)$ & $58.6(4.45)$ & $82.9(34.5)$ \\
\hline $\mathbf{3 3 6}$ & $75.7(5.36)$ & $92.6(6.55)$ & $84.2(11.9)$ & $123(8.93)$ & $118(8.74)$ & $121(3.58)$ \\
\hline
\end{tabular}

Table 3-3. Summary of Pu DFs obtained at $25^{\circ} \mathrm{C}$ after contact with SWS-7-2011-5.6. The numbers in parenthesis represent one sigma uncertainty.

\begin{tabular}{|c|c|c|c|c|c|c||}
\hline \multirow{2}{*}{$\begin{array}{c}\text { Time } \\
(\mathbf{h})\end{array}$} & $\begin{array}{c}\text { RaThMST-2 } \\
\text { (MST) }\end{array}$ & $\begin{array}{c}\text { RaThMST-3 } \\
\text { (MST) }\end{array}$ & Ave. MST & $\begin{array}{c}\text { RaThMST-4 } \\
\text { (mMST) }\end{array}$ & $\begin{array}{c}\text { RaThMST-5 } \\
\text { (mMST) }\end{array}$ & Ave. mMST \\
\hline $\mathbf{0 . 5}$ & $1.51(0.133)$ & $1.80(0.127)$ & $1.65(0.203)$ & $1.75(0.146)$ & $1.65(0.114)$ & $1.70(0.071)$ \\
\hline $\mathbf{1}$ & $1.99(0.214)$ & $1.90(0.216)$ & $1.94(0.062)$ & $2.70(0.317)$ & $2.16(0.254)$ & $2.43(0.380)$ \\
\hline $\mathbf{2}$ & $2.30(0.190)$ & $2.54(0.192)$ & $2.42(0.167)$ & $5.08(0.375)$ & $3.93(0.403)$ & $4.51(0.817)$ \\
\hline $\mathbf{4}$ & $2.33(0.176)$ & $2.45(0.182)$ & $2.39(0.083)$ & $10.7(0.768)$ & $10.6(0.763)$ & $10.7(0.069)$ \\
\hline $\mathbf{6}$ & $2.89(0.186)$ & $3.45(0.256)$ & $3.17(0.396)$ & $25.5(2.51)$ & $21.9(1.78)$ & $23.7(2.53)$ \\
\hline $\mathbf{1 2}$ & $3.64(0.308)$ & $3.76(0.319)$ & $3.70(0.082)$ & $40.3(3.86)$ & $42.4(3.79)$ & $41.3(1.48)$ \\
\hline $\mathbf{2 4}$ & $4.24(0.320)$ & $4.48(0.338)$ & $4.36(0.171)$ & $70.8(6.68)$ & $79.7(8.07)$ & $75.3(6.34)$ \\
\hline $\mathbf{1 6 8}$ & $11.7(0.877)$ & $12.0(0.892)$ & $11.8(0.236)$ & $155(15.3)$ & $164(17.3)$ & $160(6.42)$ \\
\hline $\mathbf{3 3 6}$ & $22.1(1.70)$ & $26.6(2.03)$ & $24.4(3.16)$ & $253(23.3)$ & $207(23.3)$ & $230(33.1)$ \\
\hline
\end{tabular}

Table 3-4. Summary of Np DFs obtained at $25^{\circ} \mathrm{C}$ after contact with SWS-7-2011-5.6. The numbers in parenthesis represent one sigma uncertainty.

\begin{tabular}{||c|c|c|c|c|c|c||}
\hline \multirow{2}{*}{$\begin{array}{c}\text { Time } \\
(\mathbf{h})\end{array}$} & $\begin{array}{c}\text { RaThMST-2 } \\
\text { (MST) }\end{array}$ & $\begin{array}{c}\text { RaThMST-3 } \\
\text { (MST) }\end{array}$ & Ave. MST & $\begin{array}{c}\text { RaThMST-4 } \\
\text { (mMST) }\end{array}$ & $\begin{array}{c}\text { RaThMST-5 } \\
\text { (mMST) }\end{array}$ & Ave. mMST \\
\hline $\mathbf{0 . 5}$ & $1.09(0.309)$ & $1.11(0.313)$ & $1.10(0.011)$ & $0.934(0.264)$ & $1.09(0.307)$ & $1.01(0.108)$ \\
\hline $\mathbf{1}$ & $0.944(0.267)$ & $0.927(0.262)$ & $0.935(0.012)$ & $1.22(0.344)$ & $1.28(0.361)$ & $1.25(0.043)$ \\
\hline $\mathbf{2}$ & $1.05(0.296)$ & $1.14(0.323)$ & $1.09(0.066)$ & $1.20(0.340)$ & $1.29(0.364)$ & $1.24(0.059)$ \\
\hline $\mathbf{4}$ & $1.01(0.285)$ & $1.14(0.321)$ & $1.07(0.090)$ & $1.28(0.362)$ & $1.36(0.385)$ & $1.32(0.058)$ \\
\hline $\mathbf{6}$ & $1.28(0.363)$ & $1.32(0.374)$ & $1.30(0.026)$ & $1.20(0.339)$ & $1.04(0.294)$ & $1.12(0.111)$ \\
\hline $\mathbf{1 2}$ & $1.41(0.399)$ & $1.23(0.347)$ & $1.32(0.131)$ & $1.39(0.397)$ & $1.29(0.364)$ & $1.34(0.070)$ \\
\hline $\mathbf{2 4}$ & $1.23(0.347)$ & $1.42(0.401)$ & $1.32(0.136)$ & $1.36(0.384)$ & $1.61(0.455)$ & $1.48(0.177)$ \\
\hline $\mathbf{1 6 8}$ & $2.12(0.599)$ & $2.45(0.692)$ & $2.28(0.233)$ & $1.73(0.489)$ & $1.66(0.471)$ & $1.70(0.047)$ \\
\hline $\mathbf{3 3 6}$ & $3.41(0.965)$ & $3.57(1.09)$ & $3.49(0.113)$ & $1.67(0.471)$ & $2.04(0.578)$ & $1.85(0.266)$ \\
\hline
\end{tabular}


Table 3-5. Summary of U DFs obtained at $25^{\circ} \mathrm{C}$ after contact with SWS-7-2011-5.6. The numbers in parenthesis represent one sigma uncertainty.

\begin{tabular}{|c|c|c|c|c|c|c||}
\hline \multirow{2}{*}{$\begin{array}{c}\text { Time } \\
(\mathbf{h})\end{array}$} & $\begin{array}{c}\text { RaThMST-2 } \\
\text { (MST) }\end{array}$ & $\begin{array}{c}\text { RaThMST-3 } \\
\text { (MST) }\end{array}$ & Ave. MST & $\begin{array}{c}\text { RaThMST-4 } \\
\text { (mMST) }\end{array}$ & $\begin{array}{c}\text { RaThMST-5 } \\
\text { (mMST) }\end{array}$ & Ave. mMST \\
\hline $\mathbf{0 . 5}$ & $1.05(0.296)$ & $1.07(0.302)$ & $1.06(0.015)$ & $0.970(0.274)$ & $1.02(0.288)$ & $0.995(0.035)$ \\
\hline $\mathbf{1}$ & $1.10(0.310)$ & $1.10(0.312)$ & $1.10(0.005)$ & $0.962(0.272)$ & $1.05(0.296)$ & $1.00(0.060)$ \\
\hline $\mathbf{2}$ & $1.10(0.310)$ & $1.18(0.332)$ & $1.14(0.057)$ & $1.06(0.299)$ & $1.04(0.293)$ & $1.05(0.015)$ \\
\hline $\mathbf{4}$ & $1.11(0.313)$ & $1.13(0.321)$ & $1.12(0.018)$ & $1.01(0.286)$ & $1.03(0.293)$ & $1.02(0.017)$ \\
\hline $\mathbf{6}$ & $1.21(0.342)$ & $1.22(0.344)$ & $1.21(0.006)$ & $1.02(0.288)$ & $1.04(0.295)$ & $1.03(0.018)$ \\
\hline $\mathbf{1 2}$ & $1.21(0.341)$ & $1.21(0.343)$ & $1.21(0.004)$ & $1.01(0.285)$ & $0.988(0.280)$ & $0.998(0.014)$ \\
\hline $\mathbf{2 4}$ & $1.23(0.348)$ & $1.26(0.358)$ & $1.25(0.023)$ & $1.08(0.305)$ & $1.07(0.302)$ & $1.07(0.009)$ \\
\hline $\mathbf{1 6 8}$ & $1.38(0.390)$ & $1.40(0.397)$ & $1.39(0.016)$ & $1.01(0.287)$ & $1.05(0.296)$ & $1.03(0.022)$ \\
\hline $\mathbf{3 3 6}$ & $1.44(0.406)$ & $1.44(0.406)$ & $1.44(0.000)$ & $1.03(0.292)$ & $1.04(0.293)$ & $1.03(0.003)$ \\
\hline
\end{tabular}

\subsection{Effect of Ionic Strength}

For the majority of sorbates, increasing the ionic strength leads to a decrease in the removal of a given sorbate. It is difficult to draw any conclusions regarding the effect of ionic strength on the ${ }^{226} \mathrm{Ra}$ removal, since the majority of the values fell below the MDL, resulting in greater than values for the DFs. However, there were more values above the detection limit at the highest ionic strength for mMST, indicating a possible decrease in removal at higher ionic strengths (Table 3-6). This trend was seen for ${ }^{85} \mathrm{Sr}$ and $\mathrm{Pu}$ with both MST and mMST (Figures 3-6 through 3-9). This is the same trend seen in earlier work examining the effect of ionic strength on MST and mMST performance. ${ }^{10}$ Increasing the ionic strength had the inverse effect on $\mathrm{Np}$ removal by MST, where higher DFs were obtained in the 6.6 M Na simulant (Figure 3-10). Np removal by mMST follows the expected trend, where the DFs were found to decrease slightly with increasing ionic strength (Figure 3-11). In earlier testing, increasing ionic strength was found to have no significant effect on the Np removal by MST, and resulted in a slight decrease in the removal by mMST only at the highest ionic strength tested $\left(6.5 \mathrm{M} \mathrm{Na}^{+}\right) .{ }^{10}$ The change in ionic strength had little to no effect on the $U$ removal by either sorbent (Table 3-7), consistent with earlier testing.

Table 3-6. Summary of ${ }^{226} \mathrm{Ra}$ DFs in different ionic strength simulants (4.6, 5.6, and 6.6 M $\mathrm{Na})$. Values in parenthesis represent one sigma uncertainty from a single trial.

\begin{tabular}{|c|c|c|c|c|c|c|}
\hline \multirow{3}{*}{ Time } & \multicolumn{6}{|c|}{${ }^{226}$ Ra DFs } \\
\hline & \multicolumn{3}{|c|}{ MST } & \multicolumn{3}{|c|}{ mMST } \\
\hline & $4.6 \mathrm{M} \mathrm{Na}$ & $5.6 \mathrm{M} \mathrm{Na}$ & $6.6 \mathrm{M} \mathrm{Na}$ & $4.6 \mathrm{M} \mathrm{Na}$ & $5.6 \mathrm{M} \mathrm{Na}$ & $6.6 \mathrm{M} \mathrm{Na}$ \\
\hline $6 \mathrm{~h}$ & $>66.8$ & $>59.1$ & $>40.8$ & $>63.1$ & $59.8(12.7)^{*}$ & $26.7(4.59)$ \\
\hline $12 \mathrm{~h}$ & $>72.7$ & $>67.4$ & $>49.2$ & $>58.9$ & $54.2(10.6)^{*}$ & $29.6(4.03)$ \\
\hline $24 \mathrm{~h}$ & $>67.8$ & $>71.6$ & $>58.1$ & $>67.2$ & $>70.3$ & $45.7(7.93)$ \\
\hline $336 \mathrm{~h}$ & $>55.0$ & $>50.3$ & $52.2(15.2)^{*}$ & $>58.7$ & $>52.4$ & $63.2(14.3)$ \\
\hline
\end{tabular}

Values are from a single trial (the other trial was below the detection limit). 
SRNL-STI-2012-00072

Revision 0

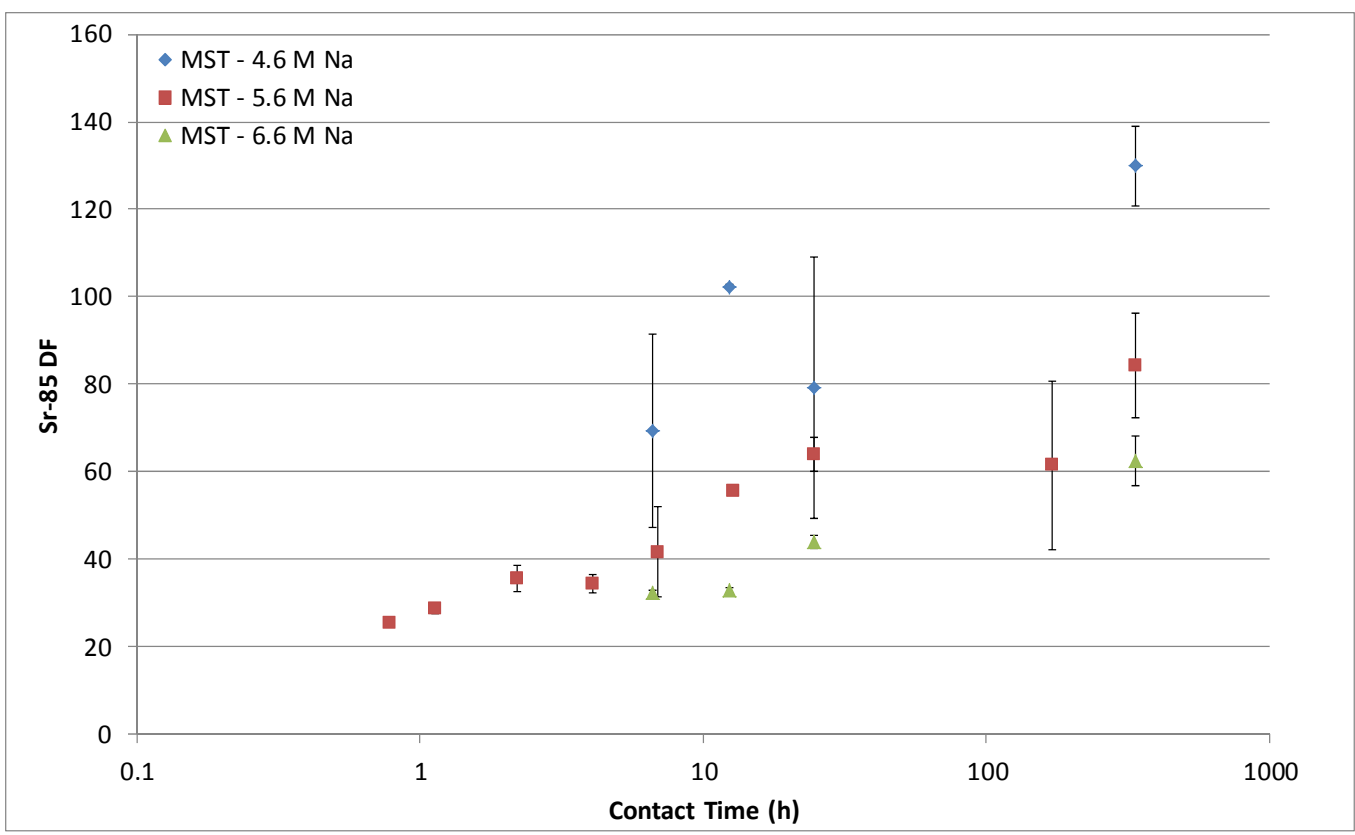

Figure 3-6. ${ }^{85} \mathrm{Sr}$ DF versus contact time with MST in various ionic strength solutions. The data points represent the average of duplicate trials, and the error bars are the standard deviations of those averages.

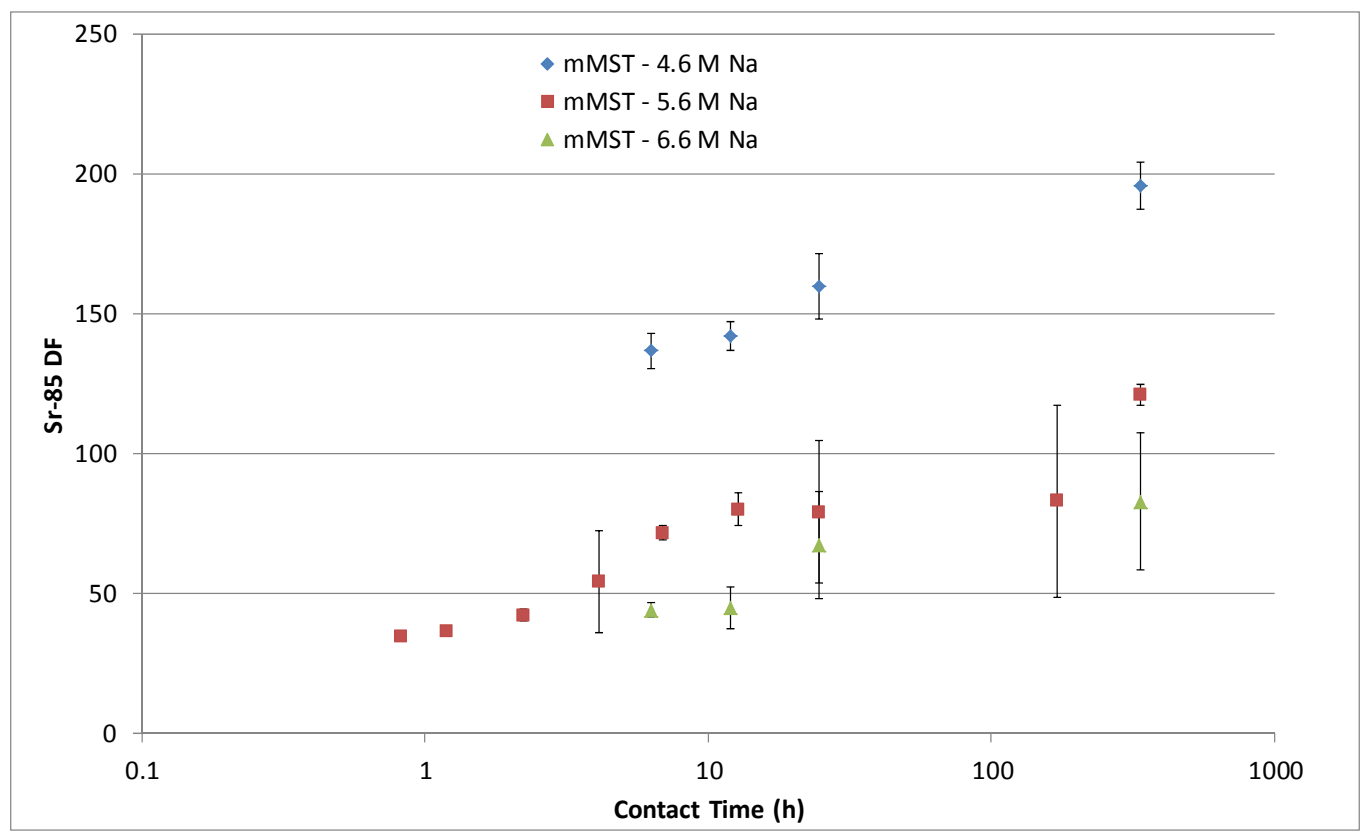

Figure 3-7. ${ }^{85} \mathrm{Sr}$ DF versus contact time with mMST in various ionic strength solutions. The data points represent the average of duplicate trials, and the error bars are the standard deviations of those averages. 


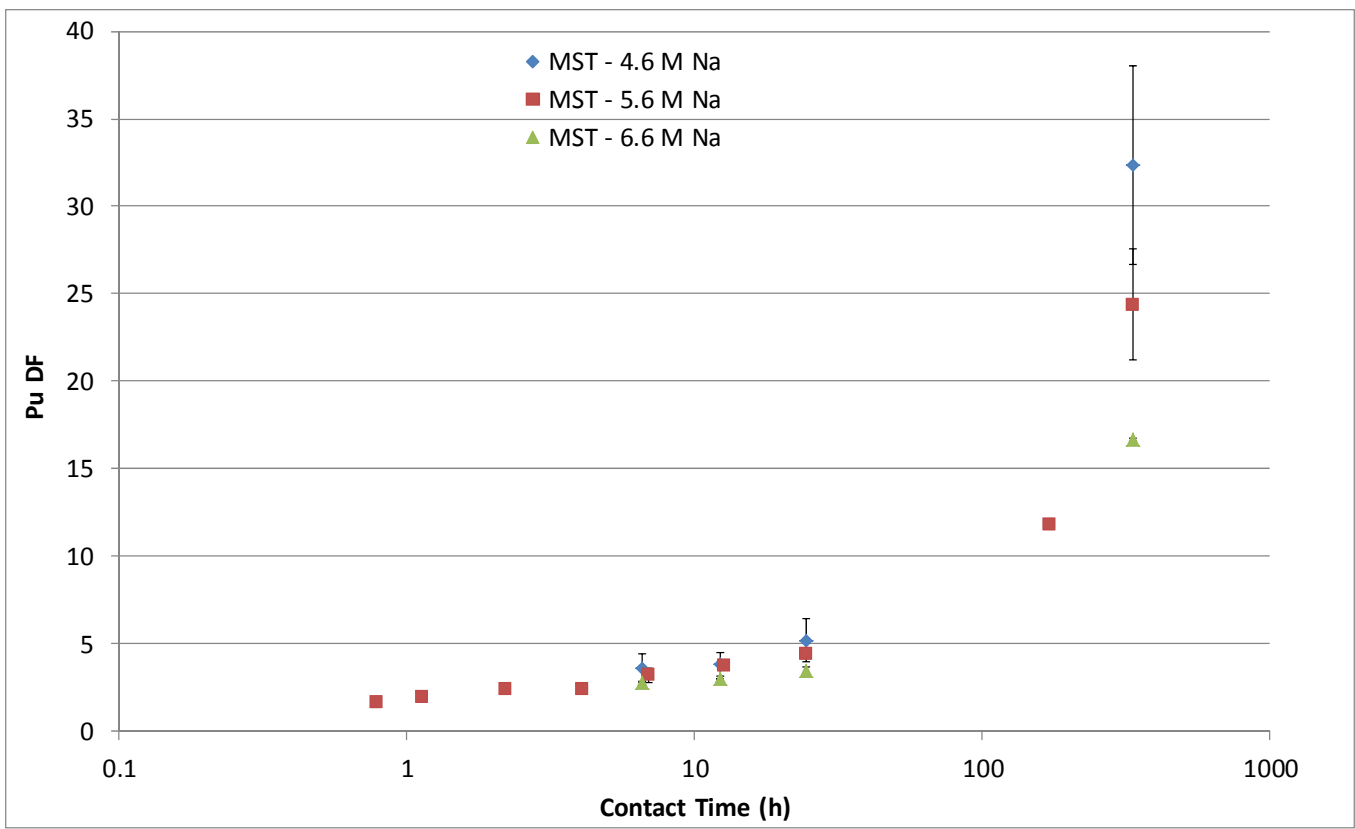

Figure 3-8. Pu DF versus contact time with MST in various ionic strength solutions. The data points represent the average of duplicate trials, and the error bars are the standard deviations of those averages.

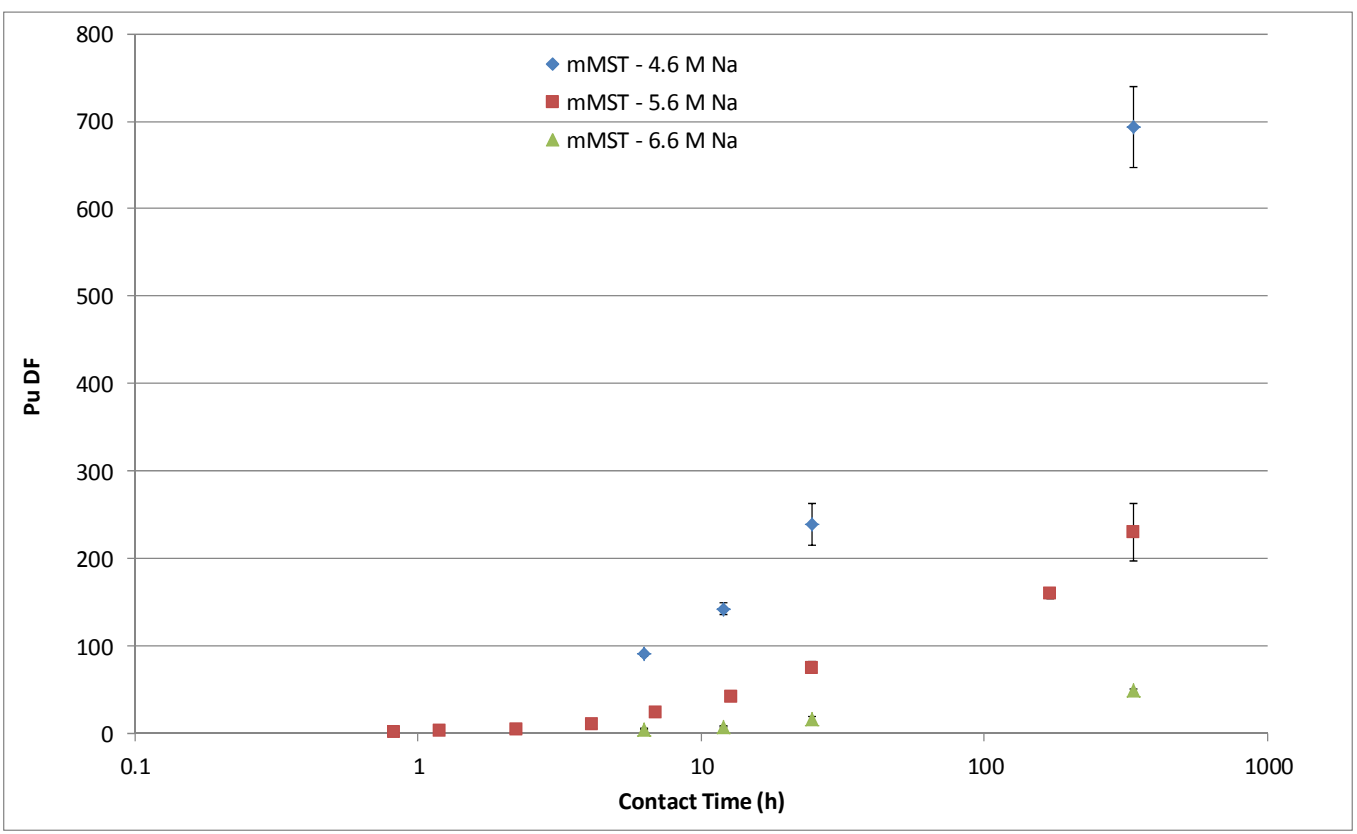

Figure 3-9. Pu DF versus contact time with mMST in various ionic strength solutions. The data points represent the average of duplicate trials, and the error bars are the standard deviations of those averages. 
SRNL-STI-2012-00072

Revision 0

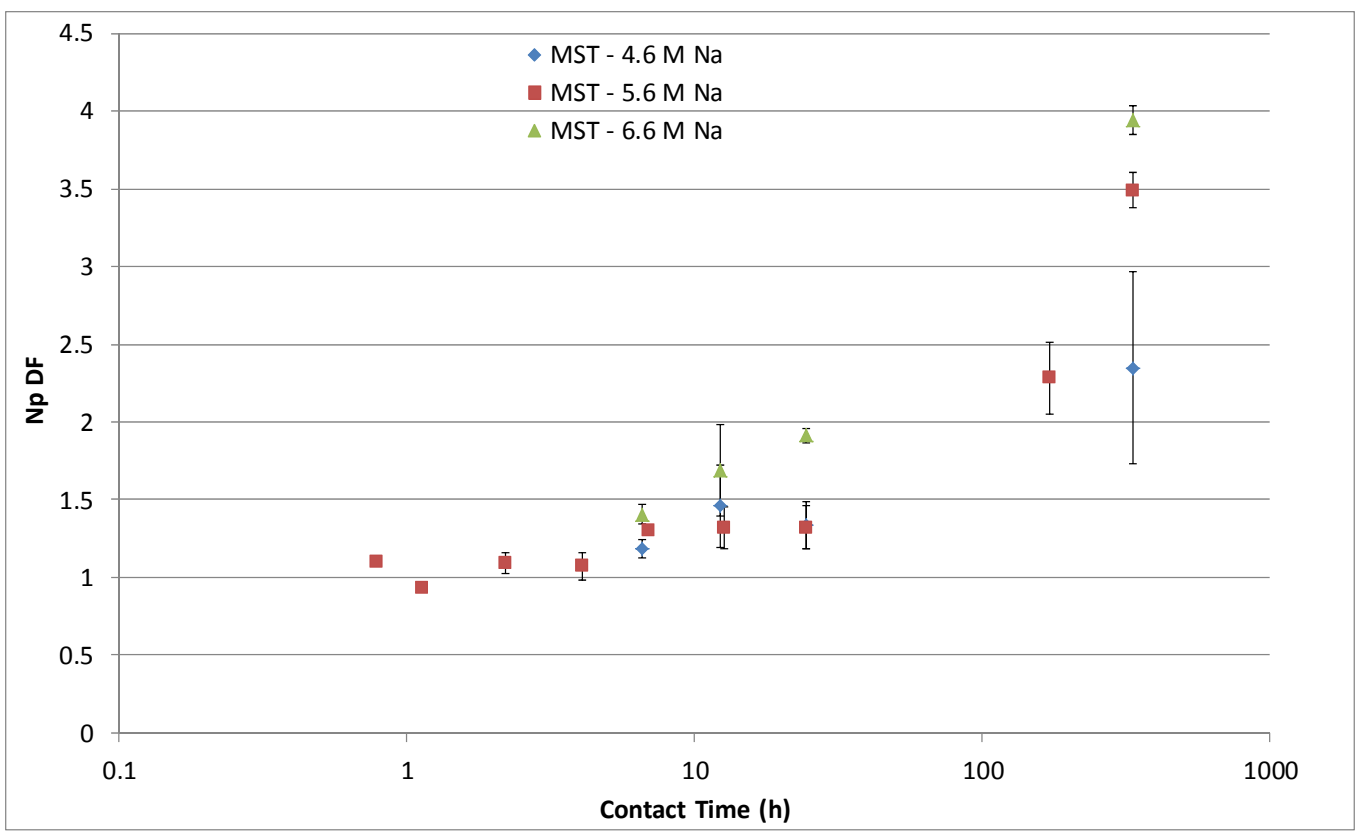

Figure 3-10. Np DF versus contact time with MST in various ionic strength solutions. The data points represent the average of duplicate trials, and the error bars are the standard deviations of those averages.

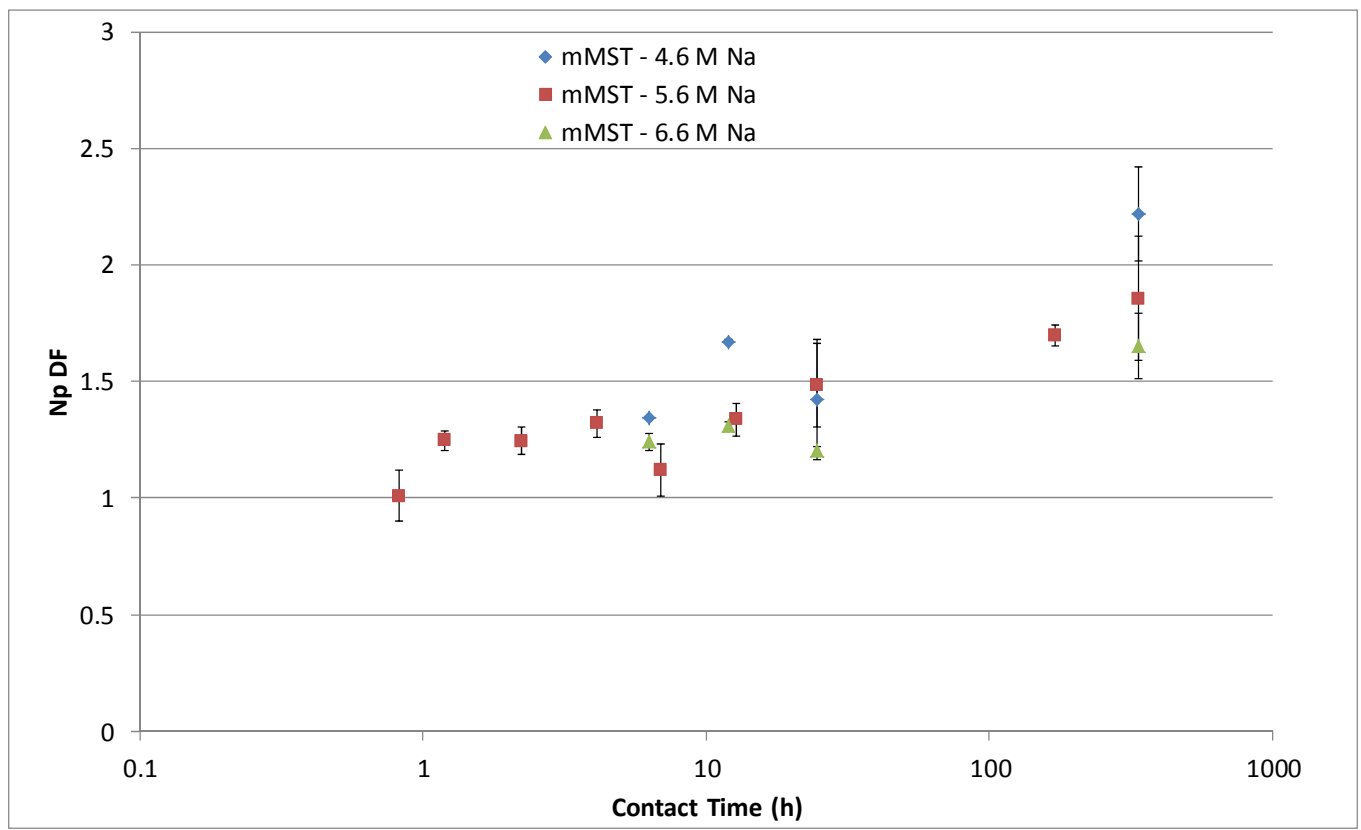

Figure 3-11. Np DF versus contact time with mMST in various ionic strength solutions. The data points represent the average of duplicate trials, and the error bars are the standard deviations of those averages. 
Table 3-7. Summary of U DFs in different ionic strength simulants (4.6, 5.6, and 6.6 M Na). Values in parenthesis represent the standard deviation of the average of duplicate trials.

\begin{tabular}{|c|c|c|c|c|c|c|}
\hline \multirow{3}{*}{ Time } & \multicolumn{6}{|c|}{ 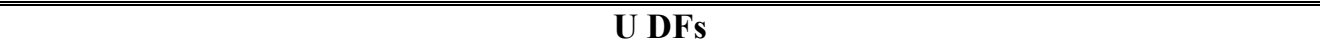 } \\
\hline & \multicolumn{3}{|c|}{ MST } & \multicolumn{3}{|c|}{ mMST } \\
\hline & $4.6 \mathrm{M} \mathrm{Na}$ & $5.6 \mathrm{M} \mathrm{Na}$ & $6.6 \mathrm{M} \mathrm{Na}$ & $4.6 \mathrm{M} \mathrm{Na}$ & $5.6 \mathrm{M} \mathrm{Na}$ & $6.6 \mathrm{M} \mathrm{Na}$ \\
\hline $6 \mathrm{~h}$ & $1.17(0.095)$ & $1.21(0.006)$ & $1.17(0.004)$ & $0.953(0.009)$ & $1.03(0.018)$ & $1.07(0.025)$ \\
\hline $12 \mathrm{~h}$ & $1.21(0.039)$ & $1.21(0.004)$ & $1.21(0.010)$ & $1.04(0.016)$ & $0.998(0.014)$ & $0.992(0.015)$ \\
\hline $24 \mathrm{~h}$ & $1.17(0.015)$ & $1.25(0.023)$ & $1.19(0.019)$ & $0.959(0.000)$ & $1.07(0.009)$ & $0.982(0.016)$ \\
\hline $336 \mathrm{~h}$ & $1.43(0.027)$ & $1.44(0.000)$ & $1.39(0.005)$ & $1.02(0.033)$ & $1.03(0.003)$ & $1.02(0.009)$ \\
\hline
\end{tabular}

\subsection{Effect of Temperature}

Increasing the temperature of the sorption experiments has varying effects on the removal of sorbates from solution. The solubilities of the sorbates at the varying temperatures were found to be similar. Plots of the control concentrations are provided in the Appendix (Figures A-6 and A-7). No conclusions can be drawn about the effect of temperature on ${ }^{226} \mathrm{Ra}$ removal, except that there does not appear to be a large adverse effect as most of the values are still below the detection limit (Table 3-9). For ${ }^{85} \mathrm{Sr}$, increasing the temperature results in a decrease in the $\mathrm{Sr}$ removal performance of both materials, as opposed to $\mathrm{Pu}$ removal, where increasing temperature appears to have a positive effect on the removal performance. For MST, the ${ }^{85} \mathrm{Sr}$ removal decreased with increasing temperature; however, the DFs for the two higher temperatures (45 and $60{ }^{\circ} \mathrm{C}$ ) were similar (Figure 3-12). A similar trend was seen for Sr removal by MST in earlier work. $^{10}$ For the mMST, at the 12 hour data point the DFs for the 2 lower temperatures were similar, while the DF at $60{ }^{\circ} \mathrm{C}$ was lower; however, at the 24 hour time point the DF decreases with increasing temperature, although there is some overlap of the error bars, indicating the change is not significant (Figure 3-13). These results are in contrast to the earlier testing, where increasing temperature had a small, but positive influence on the mMST Sr removal performance. ${ }^{10}$ The simulant used in the previous testing had a slightly different composition, including lower hydroxide and carbonate concentrations. The Pu removal by both materials was found to increase with increasing temperature, with the effect being much more pronounced for MST than for mMST (Figures 3-14 and 3-15). These results are similar to what was seen in the earlier testing, where increasing temperature resulted in increased Pu DFs for MST, but had little effect on the Pu DFs obtained with mMST. ${ }^{10-11}$ For Np, the DFs were found to increase with increasing temperature for both sorbents, although the effect was minimal for mMST (Figures 316 and 3-17). The mMST result is consistent with earlier testing, where the Np DF was found to increase slightly when the temperature was increased from 25 to $45^{\circ} \mathrm{C}$, but slightly decreased upon a further increase in temperature to $65^{\circ} \mathrm{C} .{ }^{10}$ The MST trend is opposite to what was observed in the earlier work, where increasing temperature resulted in decreased DF values. ${ }^{11}$ There was no significant effect of temperature on $U$ removal by either material, which is consistent with earlier results (Table 3-8). ${ }^{10-11}$ 
SRNL-STI-2012-00072

Revision 0

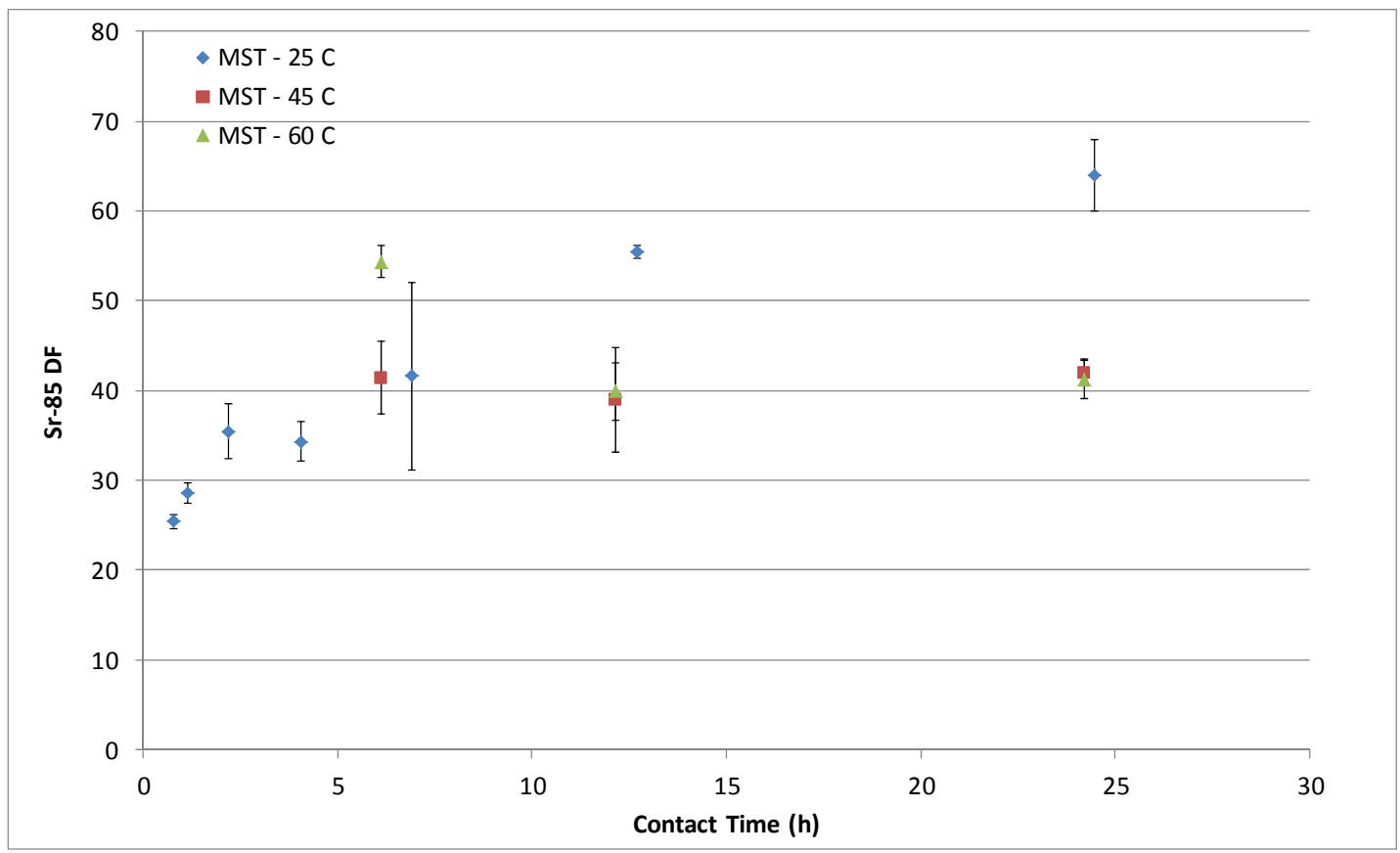

Figure 3-12. ${ }^{85} \mathrm{Sr}$ DF versus contact time with MST at various temperatures. The data points represent the average of duplicate trials, and the error bars are the standard deviations of those averages.

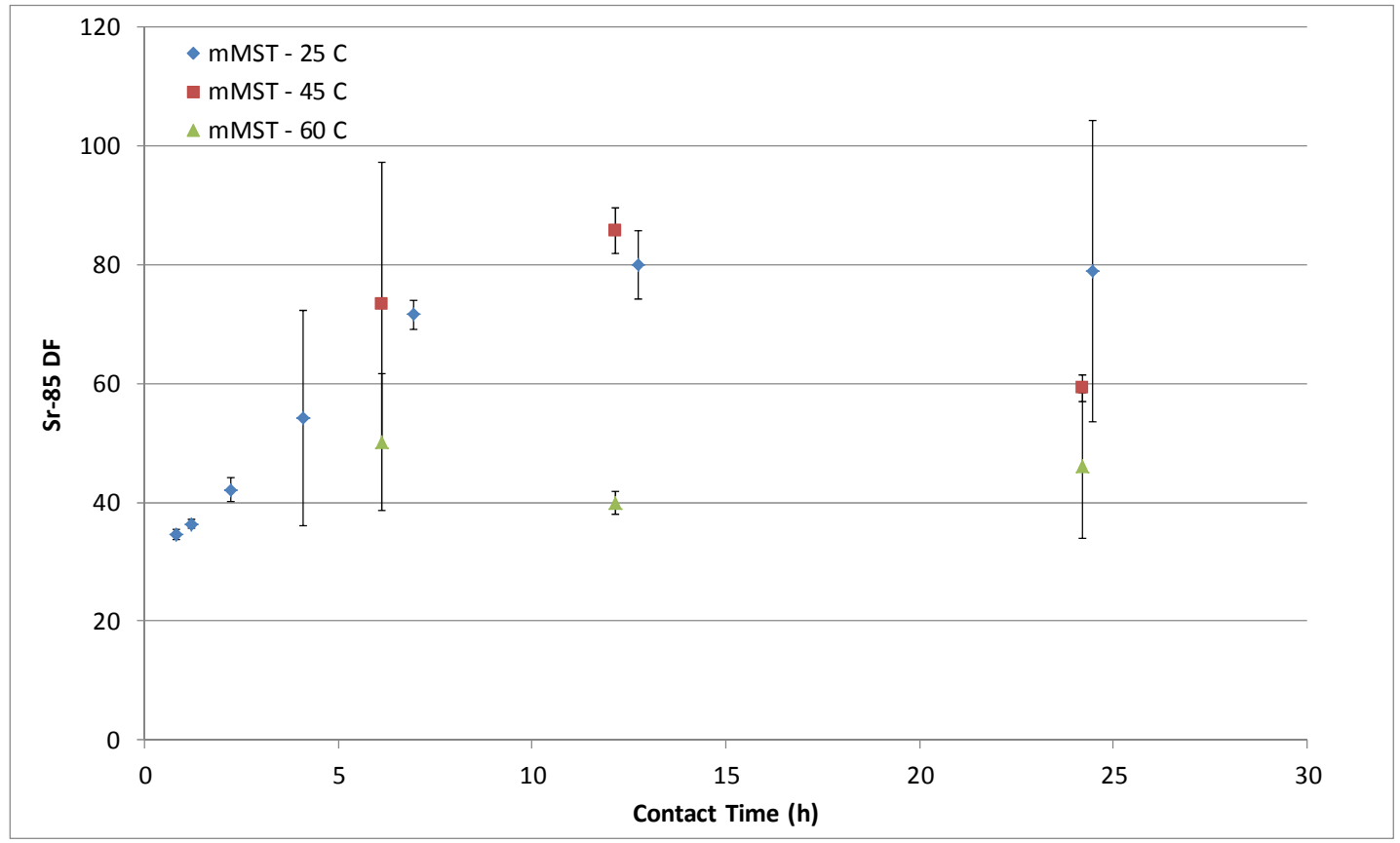

Figure 3-13. ${ }^{85} \mathrm{Sr}$ DF versus contact time with mMST at various temperatures. The data points represent the average of duplicate trials, and the error bars are the standard deviations of those averages. 
SRNL-STI-2012-00072

Revision 0

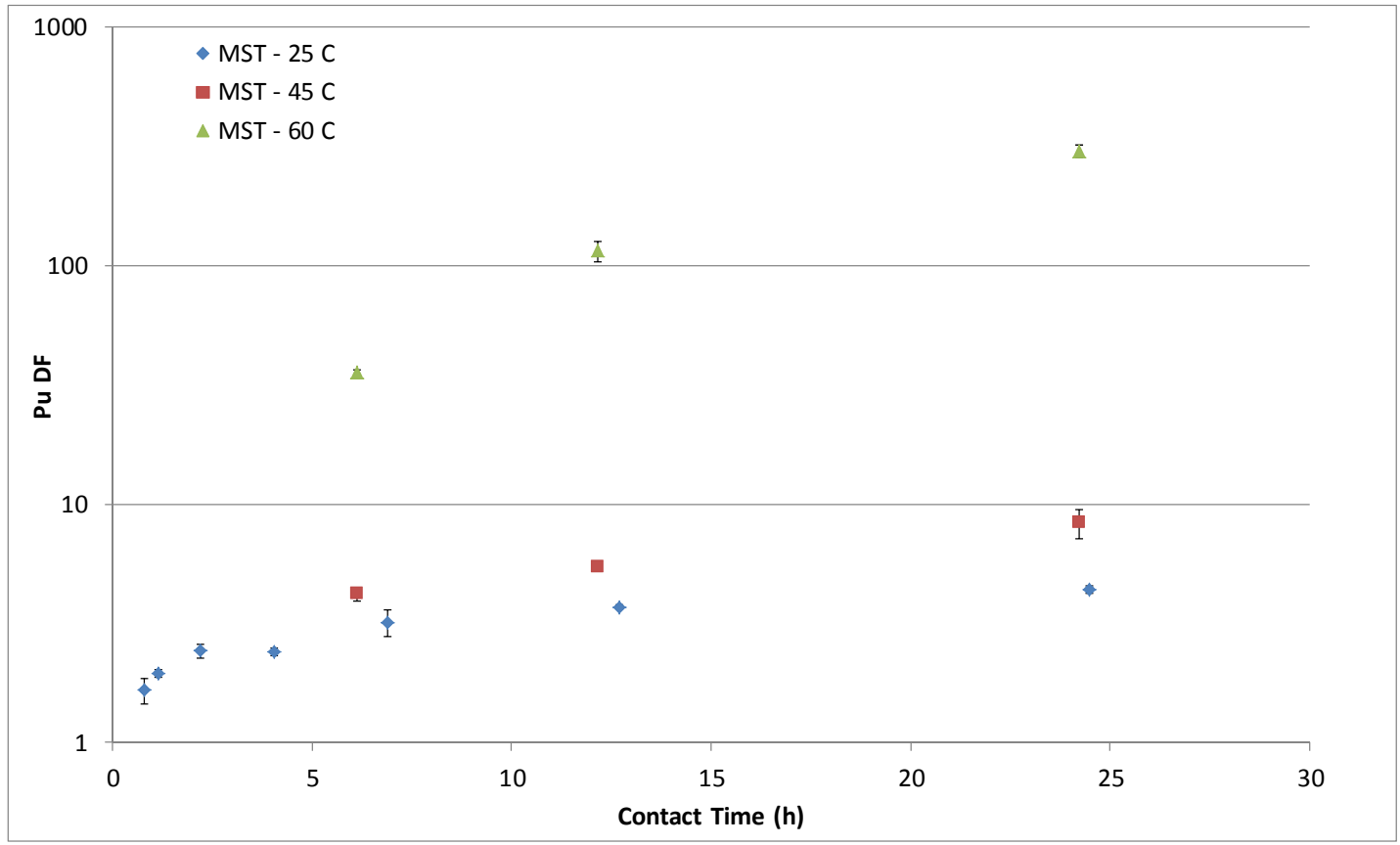

Figure 3-14. Pu DF versus contact time with MST at various temperatures. The data points represent the average of duplicate trials, and the error bars are the standard deviations of those averages.

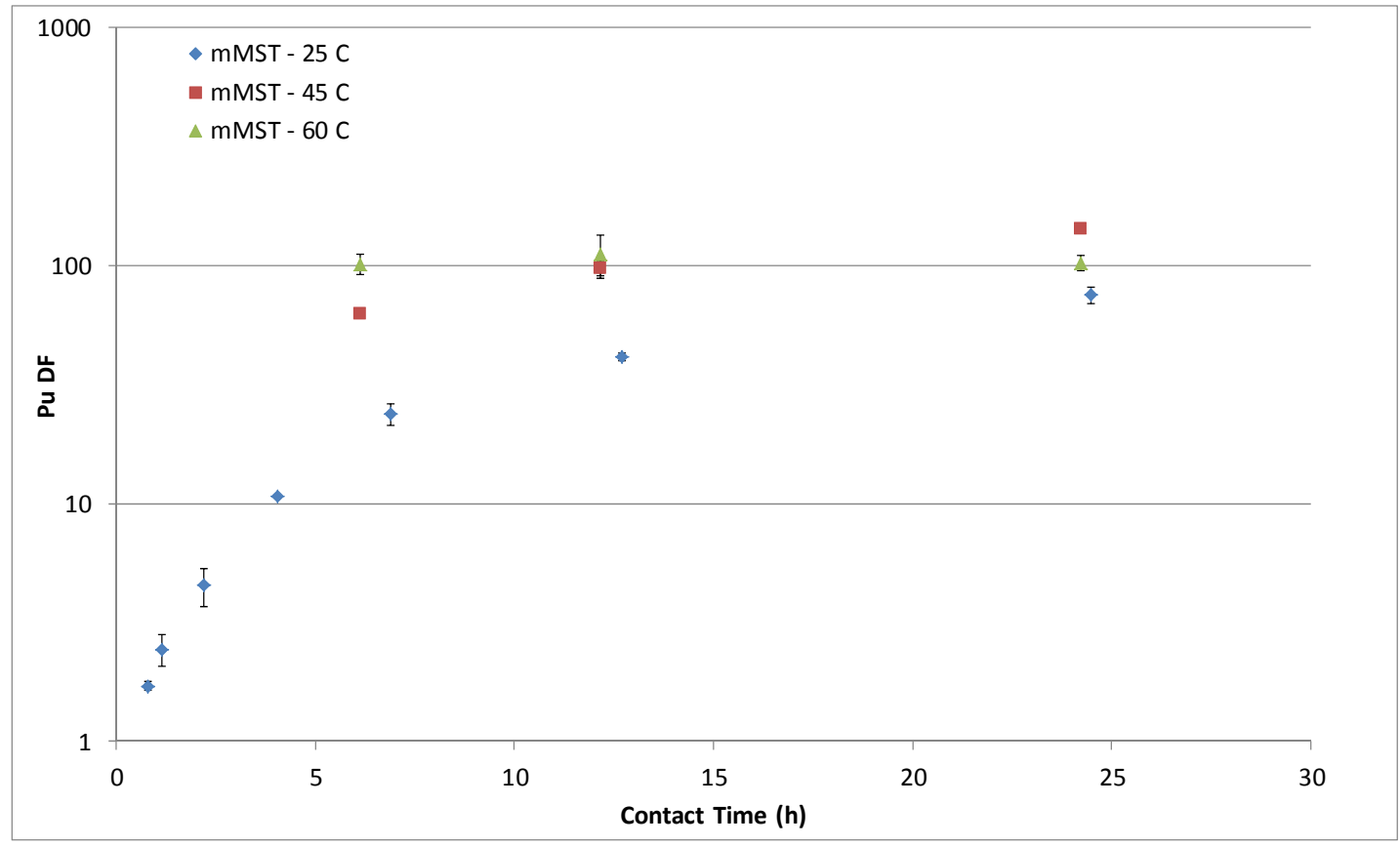

Figure 3-15. Pu DF versus contact time with mMST at various temperatures. The data points represent the average of duplicate trials, and the error bars are the standard deviations of those averages. 


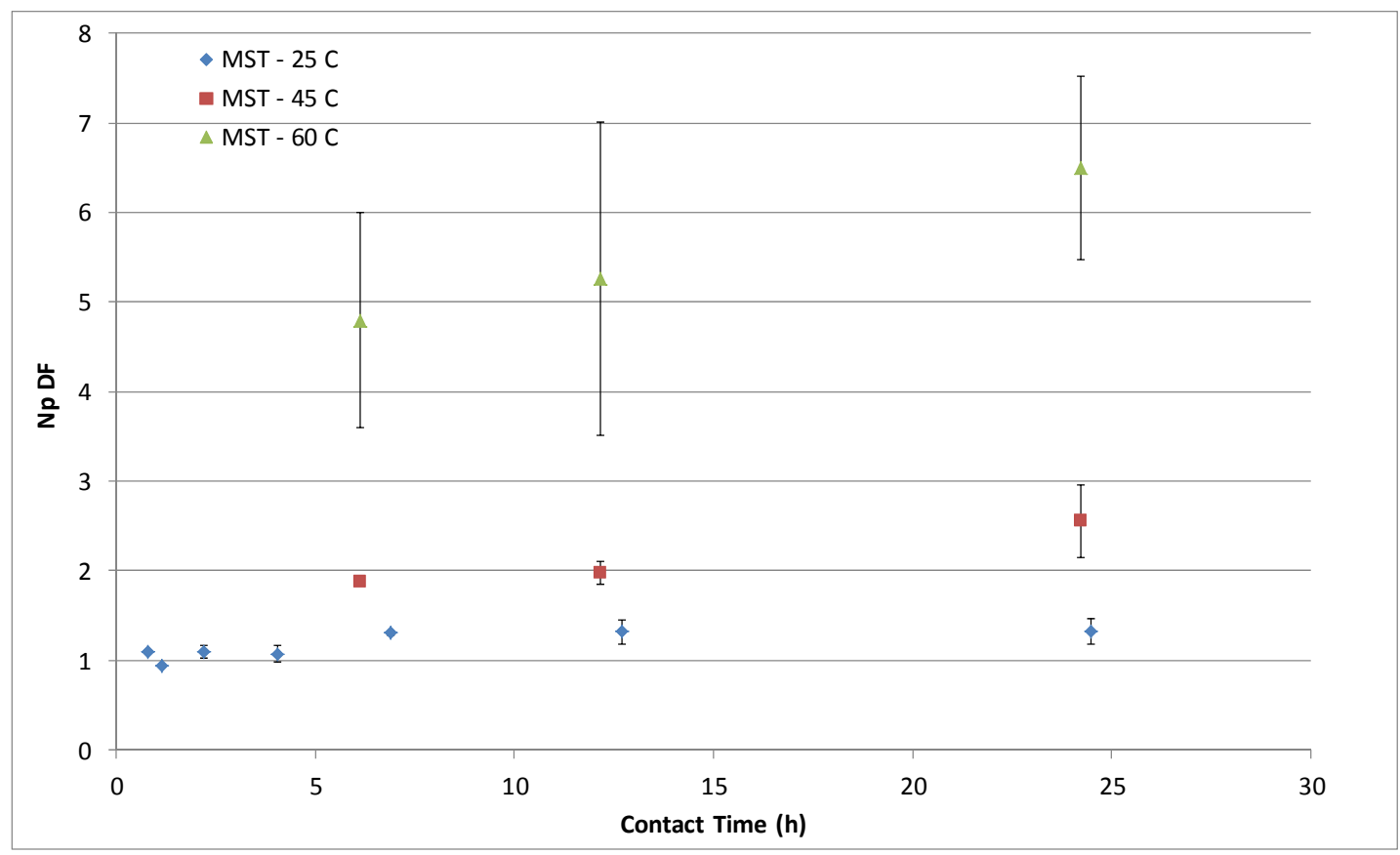

Figure 3-16. Np DF versus contact time with MST at various temperatures. The data points represent the average of duplicate trials, and the error bars are the standard deviations of those averages.

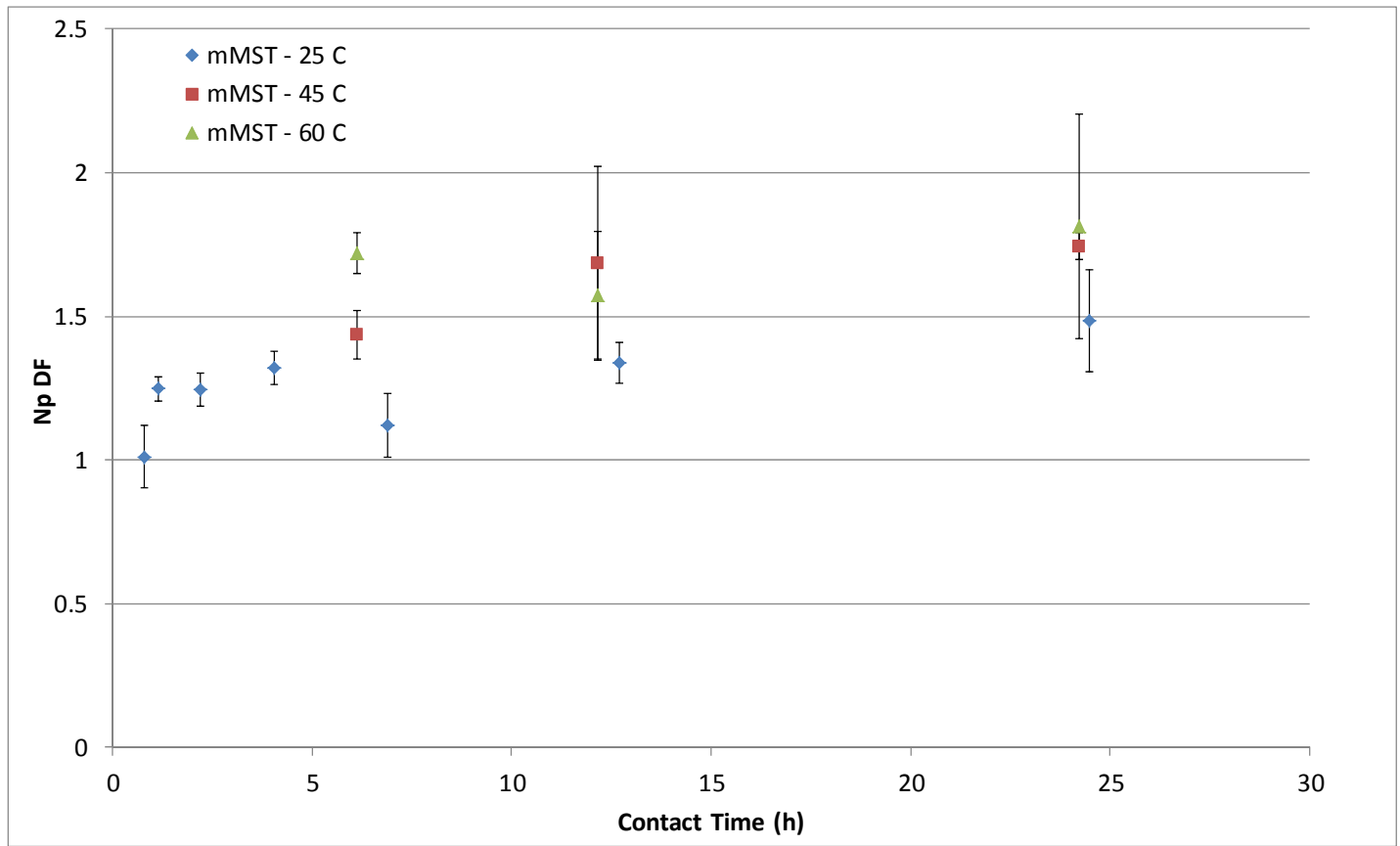

Figure 3-17. Np DF versus contact time with mMST at various temperatures. The data points represent the average of duplicate trials, and the error bars are the standard deviations of those averages. 
Table 3-8. Summary of U DFs at various temperatures. Values in parenthesis represent the standard deviation of the average of duplicate trials.

\begin{tabular}{|c|c|c|c|c|c|c|}
\hline \multirow{3}{*}{ Time } & \multicolumn{6}{|c|}{ U DFs } \\
\hline & \multicolumn{3}{|c|}{ MST } & \multicolumn{3}{|c|}{ mMST } \\
\hline & $25^{\circ} \mathrm{C}$ & $45^{\circ} \mathrm{C}$ & $60^{\circ} \mathrm{C}$ & $25^{\circ} \mathrm{C}$ & $45^{\circ} \mathrm{C}$ & $60^{\circ} \mathrm{C}$ \\
\hline $6 \mathrm{~h}$ & $1.21(0.006)$ & $1.25(0.014)$ & $1.29(0.066)$ & $1.03(0.018)$ & $1.02(0.018)$ & $1.02(0.047)$ \\
\hline $12 \mathrm{~h}$ & $1.21(0.004)$ & $1.20(0.016)$ & $1.25(0.010)$ & $0.998(0.014)$ & $0.992(0.011)$ & $0.995(0.008)$ \\
\hline $24 \mathrm{~h}$ & $1.25(0.023)$ & $1.29(0.037)$ & $1.37(0.011)$ & $1.07(0.009)$ & $0.997(0.007)$ & $1.07(0.010)$ \\
\hline
\end{tabular}

Table 3-9. Summary of ${ }^{226}$ Ra DFs at various temperatures. Values in parenthesis represent the standard deviation of the average of duplicate trials.

\begin{tabular}{|c|c|c|c|c|c|c|}
\hline \multirow{3}{*}{ Time } & \multicolumn{6}{|c|}{${ }^{226} \mathrm{Ra}$ DFs } \\
\hline & \multicolumn{3}{|c|}{ MST } & \multicolumn{3}{|c|}{ mMST } \\
\hline & $25^{\circ} \mathrm{C}$ & $45^{\circ} \mathrm{C}$ & $60^{\circ} \mathrm{C}$ & $25^{\circ} \mathrm{C}$ & $45^{\circ} \mathrm{C}$ & $60^{\circ} \mathrm{C}$ \\
\hline $6 \mathrm{~h}$ & $>59.1$ & $>64.5$ & $>63.2$ & $59.8(12.7)$ & $54.0(11.2)^{*}$ & $52.5(13.5)$ \\
\hline $12 \mathrm{~h}$ & $>67.4$ & $>49.4$ & $>73.8$ & $54.2(10.6)$ & $>53.7$ & $>56.8$ \\
\hline $24 \mathrm{~h}$ & $>71.6$ & $>59.7$ & $>42.4$ & $>70.3$ & $>61.7$ & $>40.8$ \\
\hline
\end{tabular}

*Values are from a single trial (the other trial was below the detection limit). The value in parenthesis represents one sigma uncertainty of the measurement.

\subsection{Results of Desorption Testing}

The desorption testing was performed using the DSS obtained after loading samples of MST and mMST. The DSS was diluted to two different sodium concentrations, $2.0 \mathrm{M}$ and $0.5 \mathrm{M}$, representing the intermediate and final stages of washing. These experiments were continued for a total of two weeks. During this time period, no evidence of desorption of any of the sorbates was observed for MST; however, additional sorption did occur under these conditions as evidenced by the decreasing solution concentrations (Table 3-10). Similar results were seen for mMST, where there was additional sorption of the majority of the sorbates, with the possible exception of $\mathrm{Pu}$ (Table 3-11). The ${ }^{85} \mathrm{Sr}$ and ${ }^{226} \mathrm{Ra}$ concentrations for these diluted solutions were below the quantifiable limit, except for the ${ }^{85} \mathrm{Sr}$ in the MST DSS. The U concentration in the 0.5 $\mathrm{M} \mathrm{Na}$ solution decreased from $1010 \mu \mathrm{g} / \mathrm{L}$ in the DSS to $248 \mu \mathrm{g} / \mathrm{L}$ after 24 hours, indicating additional sorption. After 2 weeks the $U$ concentration had increased to $432 \mu \mathrm{g} / \mathrm{L}$, indicating some desorption of the additional sorbed $\mathrm{U}$.

The only evidence of possible desorption was seen for Pu from mMST. In the $2 \mathrm{M}$ solution the $\mathrm{Pu}$ concentration increased from $<0.0117 \mu \mathrm{g} / \mathrm{L}$ in the DSS to $0.881 \mu \mathrm{g} / \mathrm{L}$ after 24 hours of contact with the loaded mMST. This change in concentration represents desorption of only $0.02 \%$ of the loaded $\mathrm{Pu}$. After 2 weeks of contact, the Pu concentration decreased from $0.881 \mu \mathrm{g} / \mathrm{L}$ to 0.218 $\mu \mathrm{g} / \mathrm{L}$, suggesting some resorption of the leached $\mathrm{Pu}$. There was also evidence of possible desorption in the more dilute, $0.5 \mathrm{M} \mathrm{Na}$, solution. In this case the Pu concentration in the DSS was below the detection limit $(<0.0382 \mu \mathrm{g} / \mathrm{L})$ before and after the 24 hour contact time. However, after 336 hours, the concentration of $\mathrm{Pu}$ had reached a level just above the detection limit, $0.0553 \mu \mathrm{g} / \mathrm{L}$, but this value only represents $<0.001 \%$ of the Pu leaching from the mMST. Given the very small increases in the Pu concentrations for these few samples, we believe that the increase in $\mathrm{Pu}$ concentration likely reflects either cross-contamination during the sampling, sample preparation, and sample analysis steps or perhaps the passage of small particles of mMST containing $\mathrm{Pu}$ through the syringe filters. 
The additional sorption observed in these tests is likely due to the increased concentration of sorbent in these tests $(13 \mathrm{~g} / \mathrm{L}$ vs $0.4 \mathrm{~g} / \mathrm{L})$. Significant sorption of $\mathrm{Pu}, \mathrm{Np}$, and $\mathrm{U}$ was observed for MST, and additional sorption of $\mathrm{Np}$ and $\mathrm{U}$ was observed for mMST. It cannot be determined if additional sorption of ${ }^{226} \mathrm{Ra}$ occurred during these tests, since the values were all below the MDL.

Table 3-10. Summary of MST desorption testing. Values in parenthesis represent one sigma uncertainty in the measurement.

\begin{tabular}{|c|c|c|c|c|c|c|}
\hline & \multicolumn{3}{|c|}{2 M Na Solution } & \multicolumn{3}{|c|}{ 0.5 M Na Solution } \\
\hline & DSS & $24 \mathrm{~h}$ & $336 \mathrm{~h}$ & DSS & $24 \mathrm{~h}$ & $336 \mathrm{~h}$ \\
\hline${ }^{85} \mathrm{Sr}(\mathrm{dpm} / \mathrm{mL})$ & $16.6(1.41)$ & $<9.88$ & $<12.3$ & $<10.0$ & $<9.96$ & $<12.1$ \\
\hline${ }^{226} \mathrm{Ra}(\mathrm{dpm} / \mathrm{mL})$ & $<59.2$ & $<67.4$ & $<66.6$ & $<55.8$ & $<69.2$ & $<50.6$ \\
\hline Total Pu $(\mu \mathrm{g} / \mathrm{L})$ & $4.38(0.353)$ & $<0.0362$ & $<0.0994$ & $1.17(0.118)$ & $<0.0591$ & $<0.0304$ \\
\hline $\begin{array}{c}{ }^{237} \mathrm{~Np}(\mu \mathrm{g} / \mathrm{L}) \\
\text { (ICP-MS) }\end{array}$ & 119 & $41.4(8.53)$ & $43.4(13.4)$ & 41.2 & $<40.0$ & $<$ \\
\hline $\begin{array}{c}{ }^{237} \mathrm{~Np}(\mu \mathrm{g} / \mathrm{L}) \\
(\text { gamma) }\end{array}$ & $83.2(4.16)$ & $32.1(1.76)$ & 29.4 (1.79) & $26.5(1.86)$ & $<8.25$ & $<8.45$ \\
\hline $\mathrm{U}(\mu \mathrm{g} / \mathrm{L})$ & $2,780(556)$ & $2,240(448)$ & $1,840(367)$ & 798 (219) & $68.2(13.6)$ & $69.6(24.4)$ \\
\hline
\end{tabular}

Table 3-11. Summary of mMST desorption testing. Values in parenthesis represent one sigma uncertainty in the measurement.

\begin{tabular}{|c|c|c|c|c|c|c|}
\hline & \multicolumn{3}{|c|}{2 M Na Solution } & \multicolumn{3}{|c|}{ 0.5 M Na Solution } \\
\hline & DSS & $24 \mathrm{~h}$ & $336 \mathrm{~h}$ & DSS & $24 \mathrm{~h}$ & $336 \mathrm{~h}$ \\
\hline${ }^{85} \mathrm{Sr}(\mathrm{dpm} / \mathrm{mL})$ & $<10.1$ & $<10.4$ & $<12.7$ & $<9.98$ & $<9.82$ & $<12.1$ \\
\hline${ }^{226} \mathrm{Ra}(\mathrm{dpm} / \mathrm{mL})$ & $<52.6$ & $<67.2$ & $<54.4$ & $<75.2$ & $<69.6$ & $<66.2$ \\
\hline Total Pu $(\mu \mathrm{g} / \mathrm{L})$ & $<0.0117$ & $\begin{array}{c}0.881 \\
(0.120)\end{array}$ & $\begin{array}{c}0.218 \\
(0.0659)\end{array}$ & $<0.0382$ & $<0.196$ & $\begin{array}{c}0.0553 \\
(0.0209)\end{array}$ \\
\hline $\begin{array}{c}{ }^{237} \mathbf{N p}(\mu \mathrm{g} / \mathrm{L}) \\
(\mathrm{ICP}-\mathrm{MS})\end{array}$ & $108(39.2)$ & $<40.0$ & $<40.0$ & $<40.0$ & $<40.0$ & $<40.0$ \\
\hline $\begin{array}{c}{ }^{237} \mathrm{~Np}(\mu \mathrm{g} / \mathrm{L}) \\
(\text { gamma) }\end{array}$ & $70.4(3.52)$ & $27.4(3.06)$ & $17.8(2.52)$ & $24.0(1.81)$ & $<8.32$ & $<8.34$ \\
\hline $\mathrm{U}(\mu \mathrm{g} / \mathrm{L})$ & $3,480(696)$ & $2,600(520)$ & $2,020(404)$ & $1,010(201)$ & $248(49.6)$ & $432(86.4)$ \\
\hline
\end{tabular}

\subsection{Conclusions}

This testing was designed to determine if MST and mMST could effectively remove Ra and Th from HLW. Testing was performed using simulated waste solution, in which Ra and Th were added. However, due to the extremely low solubility of $\mathrm{Th}$ at high $\mathrm{pH}$, no measureable amount of Th was incorporated into the simulant. Therefore, only the sorption of Ra was determined in this testing. Based on the reported analytical detection limits by gamma counting, the Th solubility was estimated to be below $3.0 \mathrm{E}-10 \mathrm{~g} / \mathrm{L}$ or $1.3 \mathrm{E}-12 \mathrm{M}$.

Results of the sorption testing using a $5.6 \mathrm{M} \mathrm{Na}$ simulated waste solution at $25{ }^{\circ} \mathrm{C}$ showed the ${ }^{226} \mathrm{Ra}$ sorption by both MST and mMST is rapid like that of Sr. The ${ }^{226} \mathrm{Ra}$ concentration fell below the MDL within 30 minutes of contact with MST, and within 2 hours of contact with mMST. It was difficult to draw any conclusions regarding the effects of ionic strength and temperature on the removal of ${ }^{226} \mathrm{Ra}$ by MST and mMST, since the majority of the results fell below the analytical detection limit. However, there did appear to be a slight decrease in the

${ }^{226} \mathrm{Ra}$ removal by mMST as the ionic strength increased, as evidenced by more values being above the MDL. The only conclusion that can be drawn regarding the effect of temperature on ${ }^{226} \mathrm{Ra}$ removal is that it does not appear to have a large adverse effect on the performance of either 
MST or mMST, since the majority of the concentrations are below detection at all three temperatures.

Desorption testing was also performed using solutions that represent the intermediate and final stages of washing. In these tests, no desorption of sorbates was observed for MST. For mMST, there was evidence of possible desorption of $\mathrm{Pu}$; however, the amount desorbed represents leaching of only $0.02 \%$ of the loaded $\mathrm{Pu}$. For the majority of the sorbates, additional sorption was observed. This is likely due to the increased MST solids concentrations in these tests, i.e. $13 \mathrm{~g} / \mathrm{L}$ versus $0.4 \mathrm{~g} / \mathrm{L}$ used to load the solids.

\subsection{Recommendations}

During analysis of the simulants prepared for this testing the Th solubility was found to be $<3.0 \mathrm{E}-10 \mathrm{~g} / \mathrm{L}$. We recommend additional testing be performed using simulants covering a range of compositions to determine the bounding concentration of soluble Th expected in SRS HLW solutions.

The majority of the tests reported here resulted in ${ }^{226} \mathrm{Ra}$ concentrations falling below the method detection limit after contact with the MST and mMST. This resulted in the reporting of minimum DF values. We recommend additional testing be performed with simulants containing higher concentrations of ${ }^{226} \mathrm{R}$ a to allow determination of DF values. 
SRNL-STI-2012-00072

Revision 0

\subsection{References}

1. T. E. Laupa, "Radium and Thorium Sorption by MST and mMST", HLE-TTR-2011-013, Rev. 0, May 2011.

2. K. M. L. Taylor-Pashow and D. T. Hobbs, "Task Technical and Quality Assurance Plan for Testing of Radium and Thorium Sorption by MST and mMST", SRNL-RP-201100949, Rev. 1, August 2011.

3. D. T. Hobbs, M. J. Barnes, R. L. Pulmano, K. M. Marshall, T. B. Edwards, M. G. Bronikowski, and S. D. Fink, (2005) "Strontium and Actinide Separations from High Level Nuclear Waste Solutions Using Monosodium Titanate 1. Simulant Testing." Separation Science and Technology, 40 (15): 3093.

4. M. Nyman, and D. T. Hobbs, (2006) "A Family of Peroxo-titanate Materials Tailored for Optimal Strontium and Actinide Sorption." Chem. Mater. 18 (26): 6425.

5. R. A. Peterson, "Preparation of Simulated Waste Solutions for Solvent Extraction Testing" WSRC-RP-2000-00361, Rev. 0, May 1, 2000.

6. M. J. Barnes, T. B. Edwards, D. T. Hobbs, and K. M. Marshall, "Strontium and Actinide Removal Testing with Monosodium Titanate and Other Sorbents" WSRC-TR-200100436, Rev. 0, October 29, 2001.

7. M. E. Stallings, M. J. Barnes, T. B. Peters, D. P. Diprete, F. F. Fondeur, D. T. Hobbs, and S. D. Fink, "Characterization of Supernate Samples from High Level Waste Tanks 13H, 30H, 37H, 39H, 45F, 46F, and 49H”, WSRC-TR-2004-00386, Rev. 2, June 2005.

8. V. Neck and J. I. Kim, Radiochim. Acta, 2001, 89, 1-16.

9. D. T. Hobbs, M. D. Nyman, T. B. Peters, M. R. Poirier, M. J. Barnes, M. E. Thompson, and S. D. Fink, "Tailoring Inorganic Sorbents for SRS Strontium and Actinide Separations: Optimized Monosodium Titanate Phase II Final Report", WSRC-STI-200700082, Rev. 0, June 2007.

10. D. T. Hobbs, "Improved Strontium and Actinide Separations Modified Monosodium Titanate Final Report of FY2008 Testing Activities" SRNL-STI-2008-00390, Rev. 0, December 2008.

11. D. T. Hobbs, M. G. Bronikowski, T. B. Edwards, and R. L. Pulmano, "Final Report on Phase III Testing of Monosodium Titanate Adsorption Kinetics" WSRC-TR-99-00134, Rev. 0, May 28, 1999. 
SRNL-STI-2012-00072

Revision 0

Appendix A.

A-1 
SRNL-STI-2012-00072

Revision 0

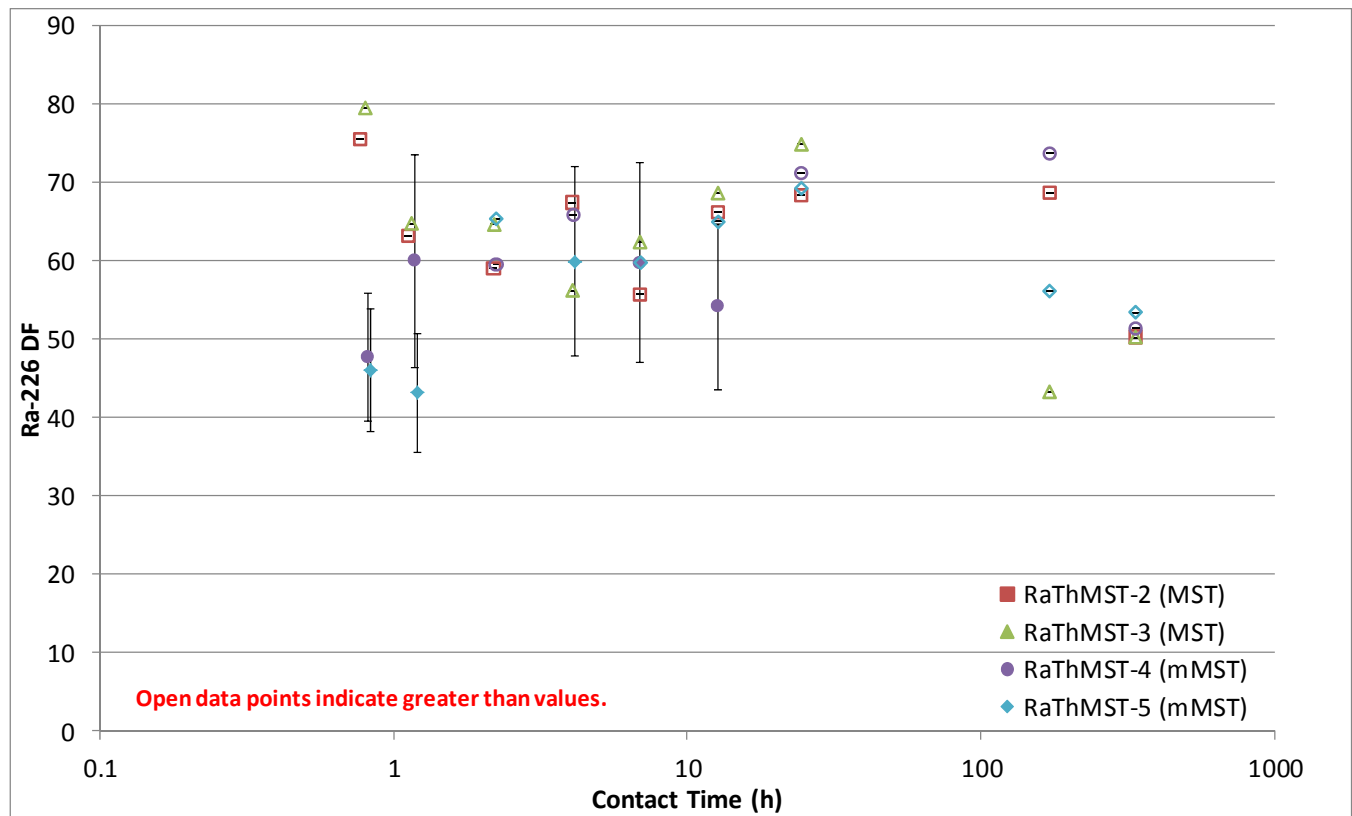

Figure A-1. ${ }^{226} \mathrm{Ra} \mathrm{DF}$ versus contact time for Tests $2-5\left(25^{\circ} \mathrm{C}, 5.6 \mathrm{M} \mathrm{Na}\right)$. Open data points identify minimum DF values.

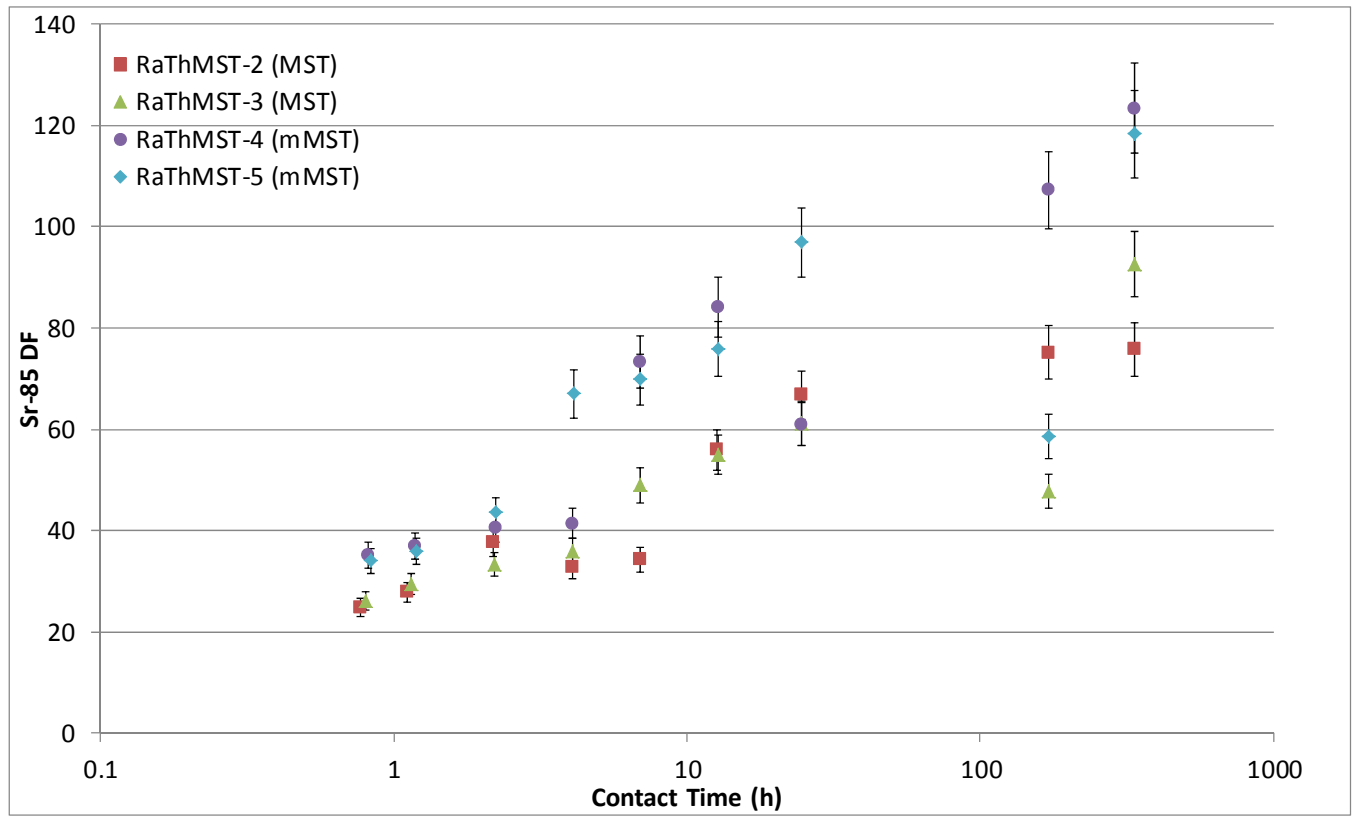

Figure A-2. ${ }^{85} \mathrm{Sr}$ DF versus contact time for Tests $2-5\left(25^{\circ} \mathrm{C}, 5.6 \mathrm{M} \mathrm{Na}\right)$. 
SRNL-STI-2012-00072

Revision 0

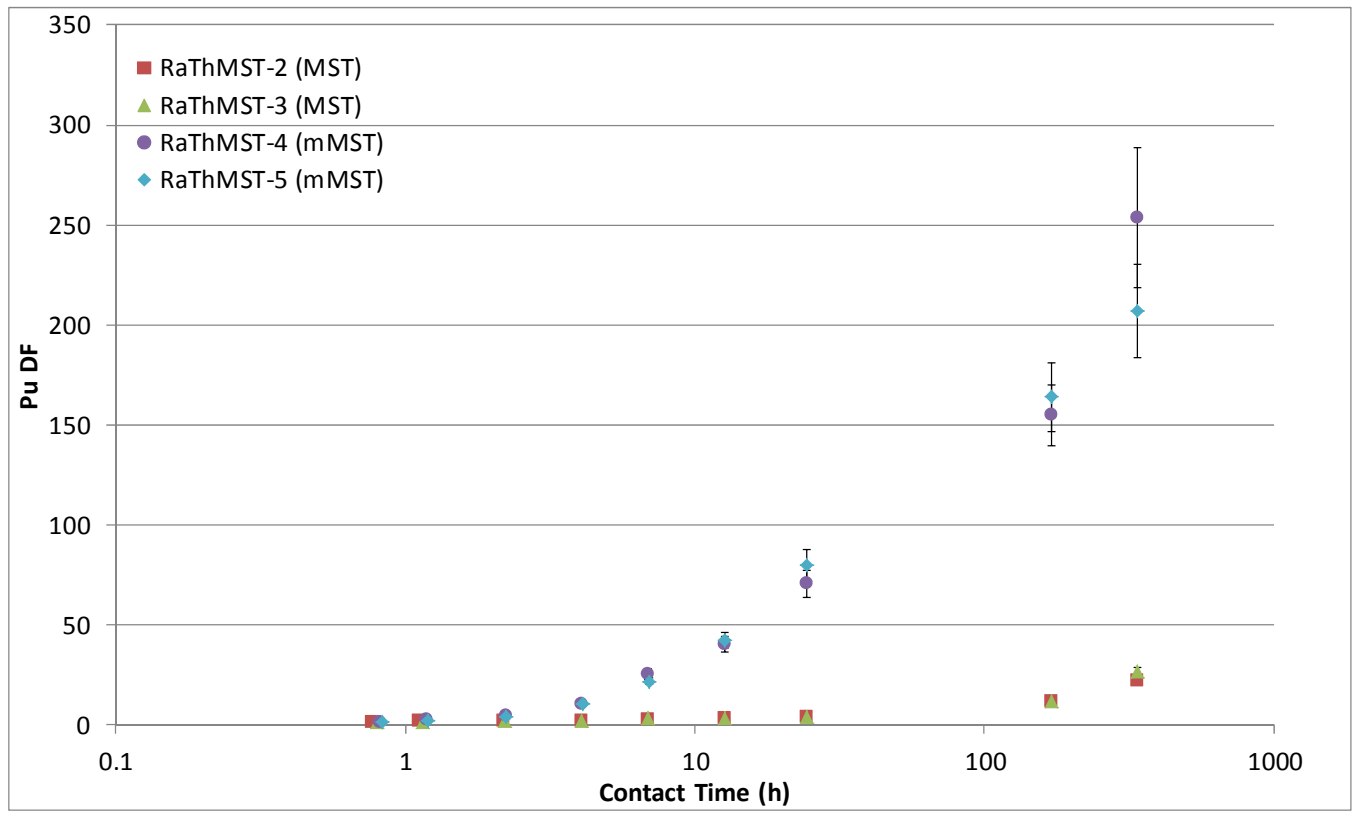

Figure A-3. Pu DF versus contact time for Tests $2-5\left(25^{\circ} \mathrm{C}, 5.6 \mathrm{M} \mathrm{Na}\right)$.

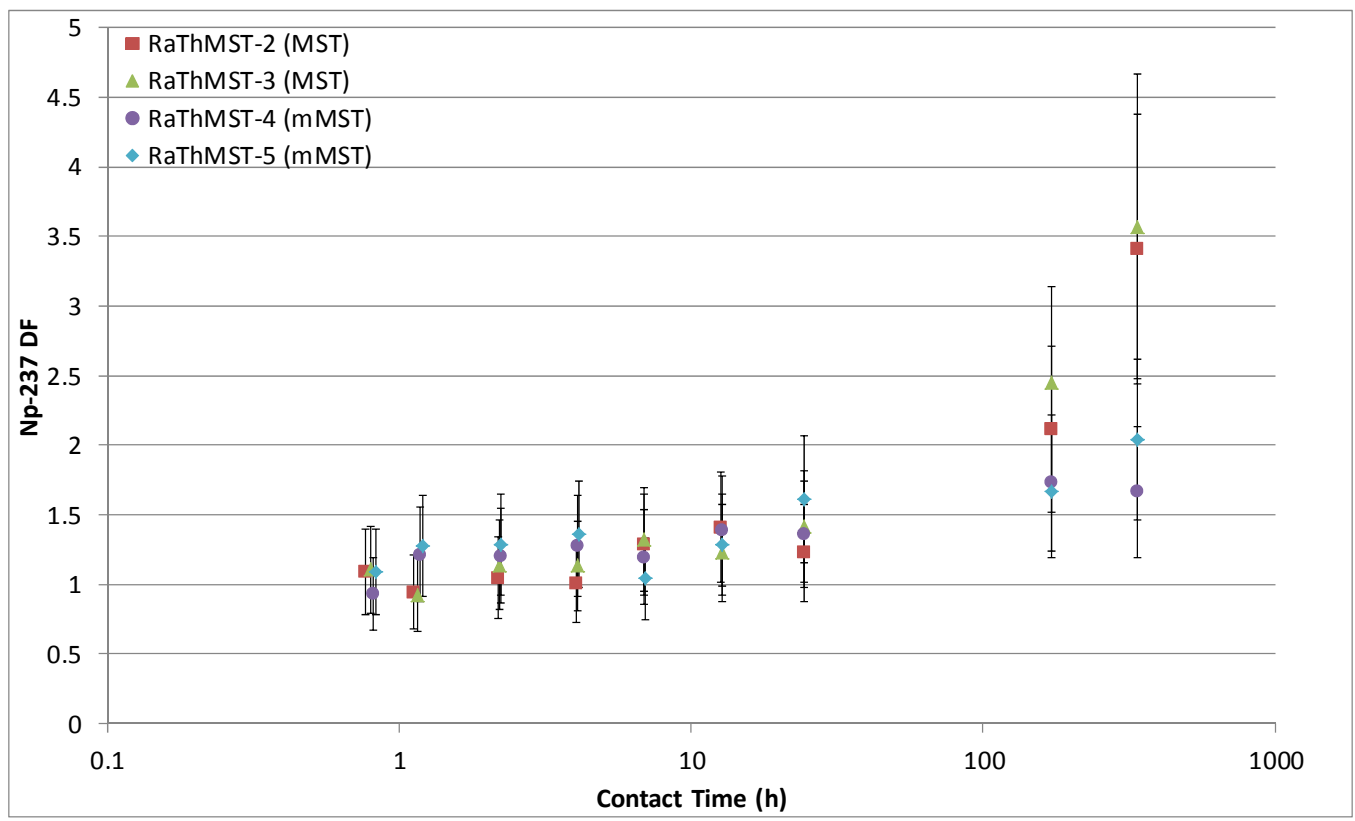

Figure A-4. ${ }^{237} \mathrm{~Np}$ DF versus contact time for Tests $2-5\left(25^{\circ} \mathrm{C}, 5.6 \mathrm{M} \mathrm{Na}\right)$. 


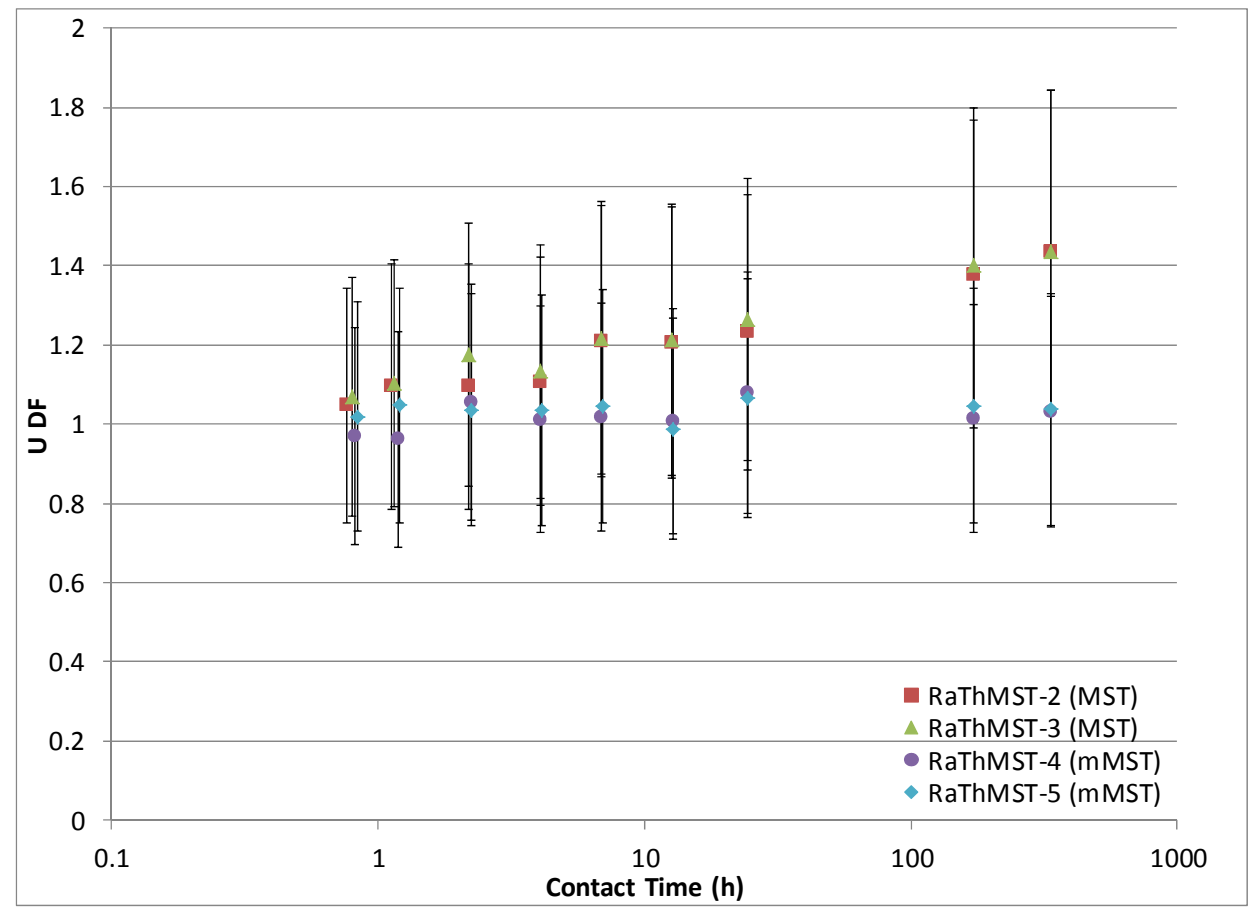

Figure A-5. U DF versus contact time for Tests $2-5\left(25^{\circ} \mathrm{C}, 5.6 \mathrm{M} \mathrm{Na}\right)$.

Table A-1. Comparison of ${ }^{85} \mathrm{Sr}$ DFs in different ionic strength simulants (4.6, 5.6, and 6.6 M $\mathrm{Na})$. Values in parenthesis represent the standard deviation of the average of the two trials.

\begin{tabular}{|c|c|c|c|c|c|c|}
\hline \multirow{3}{*}{ Time } & \multicolumn{6}{|c|}{${ }^{\overline{85}} \mathrm{Sr}$ DFs } \\
\hline & \multicolumn{3}{|c|}{ MST } & \multicolumn{3}{|c|}{ mMST } \\
\hline & $4.6 \mathrm{M} \mathrm{Na}$ & $5.6 \mathrm{M} \mathrm{Na}$ & $6.6 \mathrm{M} \mathrm{Na}$ & $4.6 \mathrm{M} \mathrm{Na}$ & $5.6 \mathrm{M} \mathrm{Na}$ & $6.6 \mathrm{M} \mathrm{Na}$ \\
\hline $6 \mathrm{~h}$ & $69.3(22.1)$ & $41.6(10.4)$ & $32.2(0.830)$ & $137(6.39)$ & $71.6(2.49)$ & $44.0(2.64)$ \\
\hline $12 \mathrm{~h}$ & $102(0.417)$ & $55.4(0.70)$ & $32.9(0.573)$ & $142(5.12)$ & $80.0(5.77)$ & $44.9(7.44)$ \\
\hline $24 \mathrm{~h}$ & $79.3(29.9)$ & $63.9(3.98)$ & $43.9(1.57)$ & $160(11.6)$ & $79.0(25.4)$ & $67.2(19.2)$ \\
\hline $336 \mathrm{~h}$ & $130(9.23)$ & $84.2(11.9)$ & $62.5(5.60)$ & $196(8.37)$ & $121(3.58)$ & $82.8(24.6)$ \\
\hline
\end{tabular}

Table A-2. Comparison of Pu DFs in different ionic strength simulants (4.6, 5.6, and 6.6 M $\mathrm{Na})$. Values in parenthesis represent the standard deviation of the average of the two trials.

\begin{tabular}{|c|c|c|c|c|c|c|}
\hline \multirow{3}{*}{ Time } & \multicolumn{6}{|c|}{ Pu DFs } \\
\hline & \multicolumn{3}{|c|}{ MST } & \multicolumn{3}{|c|}{ mMST } \\
\hline & $4.6 \mathrm{M} \mathrm{Na}$ & $5.6 \mathrm{M} \mathrm{Na}$ & $6.6 \mathrm{M} \mathrm{Na}$ & $4.6 \mathrm{M} \mathrm{Na}$ & $5.6 \mathrm{M} \mathrm{Na}$ & 6.6 M Na \\
\hline $6 \mathrm{~h}$ & $3.60(0.823)$ & $3.17(0.396)$ & $2.73(0.102)$ & $90.3(2.49)$ & $23.7(2.53)$ & $4.66(0.408)$ \\
\hline $12 \mathrm{~h}$ & $3.80(0.656)$ & $3.70(0.082)$ & $2.99(0.008)$ & $142(6.55)$ & $41.3(1.48)$ & $7.48(0.688)$ \\
\hline $24 \mathrm{~h}$ & $5.17(1.21)$ & $4.36(0.171)$ & $3.42(0.209)$ & 2391 & $75.3(6.34)$ & $16.0(3.37)$ \\
\hline $336 \mathrm{~h}$ & $32.3(5.69)$ & $24.4(3.16)$ & $16.7(0.084)$ & $693(45.7)$ & $230(33.1)$ & $48.7(2.61)$ \\
\hline
\end{tabular}


Table A-3. Comparison of Np DFs in different ionic strength simulants $(4.6,5.6$, and 6.6 M $\mathrm{Na})$. Values in parenthesis represent the standard deviation of the average of the two trials.

\begin{tabular}{|c|c|c|c|c|c|c|}
\hline \multirow{3}{*}{ Time } & \multicolumn{6}{|c|}{ Np DFs } \\
\hline & \multicolumn{3}{|c|}{ MST } & \multicolumn{3}{|c|}{ mMST } \\
\hline & $4.6 \mathrm{M} \mathrm{Na}$ & $5.6 \mathrm{M} \mathrm{Na}$ & $6.6 \mathrm{M} \mathrm{Na}$ & $4.6 \mathrm{M} \mathrm{Na}$ & $5.6 \mathrm{M} \mathrm{Na}$ & $6.6 \mathrm{M} \mathrm{Na}$ \\
\hline $6 \mathrm{~h}$ & $1.18(0.057)$ & $1.30(0.026)$ & $1.41(0.064)$ & $1.34(0.005)$ & $1.12(0.111)$ & $1.24(0.036)$ \\
\hline $12 \mathrm{~h}$ & $1.46(\mathrm{C}$ & $(0.131)$ & $1.69(0.295)$ & $1.67(0.007)$ & $1.34(0.070)$ & $1.31(0.015)$ \\
\hline $24 \mathrm{~h}$ & 1.34( & 1.2 & 1.9 & $1.42(0.256)$ & $1.48(0.177)$ & $1.20(0.018)$ \\
\hline $336 \mathrm{~h}$ & $2.35(0.615)$ & $3.49(0.113)$ & $3.94(0.092)$ & $2.22(0.202)$ & $1.85(0.266)$ & $1.65(0.137)$ \\
\hline
\end{tabular}

Table A-4. Comparison of ${ }^{85} \mathrm{Sr}$ DFs at different temperatures in the 5.6 M Na simulant (25, 45 , and $60^{\circ} \mathrm{C}$ ). Values in parenthesis represent the standard deviation of the average of the two trials.

\begin{tabular}{|c|c|c|c|c|c|c|}
\hline \multirow{3}{*}{ Time } & \multicolumn{6}{|c|}{${ }^{85} \mathrm{Sr}$ DFs } \\
\hline & \multicolumn{3}{|c|}{ MST } & \multicolumn{3}{|c|}{ mMST } \\
\hline & $25^{\circ} \mathrm{C}$ & $45^{\circ} \mathrm{C}$ & $60^{\circ} \mathrm{C}$ & $25^{\circ} \mathrm{C}$ & $45^{\circ} \mathrm{C}$ & $60^{\circ} \mathrm{C}$ \\
\hline $6 \mathrm{~h}$ & $41.6(10.4)$ & $41.4(4.05)$ & $54.4(1.75)$ & $121(3.58)$ & $73.4(24.0)$ & $50.1(11.5)$ \\
\hline $12 \mathrm{~h}$ & $55.4(0.70)$ & $39.0(5.82)$ & $39.9(3.26)$ & $71.6(2.49)$ & $85.8(3.82)$ & 39.9 (1.99) \\
\hline $24 \mathrm{~h}$ & $63.9(3.98)$ & $41.9(1.45)$ & $41.3(2.15)$ & $80.0(5.77)$ & $59.2(2.24)$ & $46.2(12.3)$ \\
\hline
\end{tabular}

Table A-5. Comparison of Pu DFs at different temperatures in the 5.6 M Na simulant (25, 45 , and $60^{\circ} \mathrm{C}$ ). Values in parenthesis represent the standard deviation of the average of the two trials.

\begin{tabular}{|c|c|c|c|c|c|c|}
\hline \multirow{3}{*}{ Time } & \multicolumn{7}{|c|}{ Mu DF } \\
\cline { 2 - 7 } & \multicolumn{7}{|c|}{ MST } & \multicolumn{3}{c||}{$\mathbf{m M S T}$} \\
\cline { 2 - 7 } & $\mathbf{2 5}^{\circ} \mathbf{C}$ & $\mathbf{4 5}^{\circ} \mathbf{C}$ & $\mathbf{6 0}^{\circ} \mathbf{C}$ & $\mathbf{2 5}^{\circ} \mathbf{C}$ & $\mathbf{4 5}^{\circ} \mathbf{C}$ & $\mathbf{6 0}^{\circ} \mathbf{C}$ \\
\hline $\mathbf{6 ~ h}$ & $3.17(0.396)$ & $4.19(0.262)$ & $35.5(1.00)$ & $23.7(2.53)$ & $62.7(1.47)$ & $102(9.88)$ \\
\hline $\mathbf{1 2} \mathbf{~ h}$ & $3.70(0.082)$ & $5.44(0.032)$ & $115(11.7)$ & $41.3(1.48)$ & $98.0(7.37)$ & $111(22.4)$ \\
\hline $\mathbf{2 4} \mathbf{h}$ & $4.36(0.171)$ & $8.33(1.15)$ & $301(18.3)$ & $75.3(6.34)$ & $143(1.29)$ & $103(7.42)$ \\
\hline
\end{tabular}

Table A-6. Comparison of Np DFs at different temperatures in the 5.6 M Na simulant (25, 45 , and $60^{\circ} \mathrm{C}$ ). Values in parenthesis represent the standard deviation of the average of the two trials.

\begin{tabular}{|c|c|c|c|c|c|c|}
\hline \multirow{3}{*}{ Time } & \multicolumn{6}{|c|}{ Np DFs } \\
\hline & \multicolumn{3}{|c|}{ MST } & \multicolumn{3}{|c|}{ mMST } \\
\hline & $25^{\circ} \mathrm{C}$ & $45^{\circ} \mathrm{C}$ & $60^{\circ} \mathrm{C}$ & $25^{\circ} \mathrm{C}$ & $45^{\circ} \mathrm{C}$ & $60^{\circ} \mathrm{C}$ \\
\hline $6 \mathrm{~h}$ & $1.30(0.026)$ & $1.88(0.019)$ & $4.80(1.20)$ & $1.12(0.111)$ & $1.43(0.084)$ & $1.72(0.072)$ \\
\hline $12 \mathrm{~h}$ & $1.32(0.131)$ & $1.97(0.129)$ & $5.26(1.75)$ & $1.34(0.070)$ & $1.69(0.338)$ & $1.57(0.222)$ \\
\hline $24 \mathrm{~h}$ & $1.32(0.136)$ & $2.56(0.408)$ & $6.50(1.03)$ & $1.48(0.177)$ & $1.74(0.045)$ & $1.81(0.391)$ \\
\hline
\end{tabular}


SRNL-STI-2012-00072

Revision 0

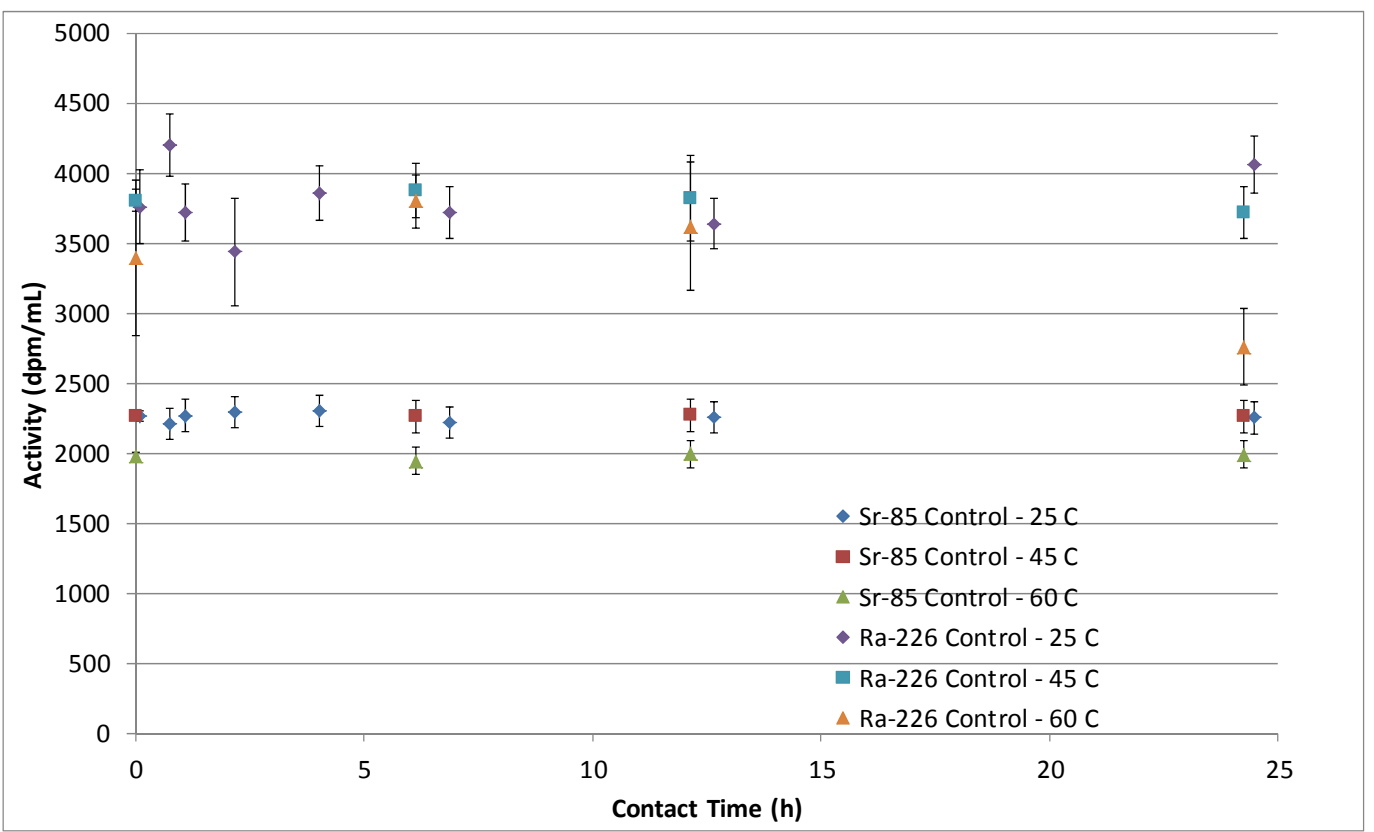

Figure A-6. ${ }^{85} \mathrm{Sr}$ and ${ }^{226} \mathrm{Ra}$ activity in control samples from Tests 1-5 $\left(25^{\circ} \mathrm{C}\right), 16-20\left(45^{\circ} \mathrm{C}\right)$, and $21-25\left(60^{\circ} \mathrm{C}\right)$.

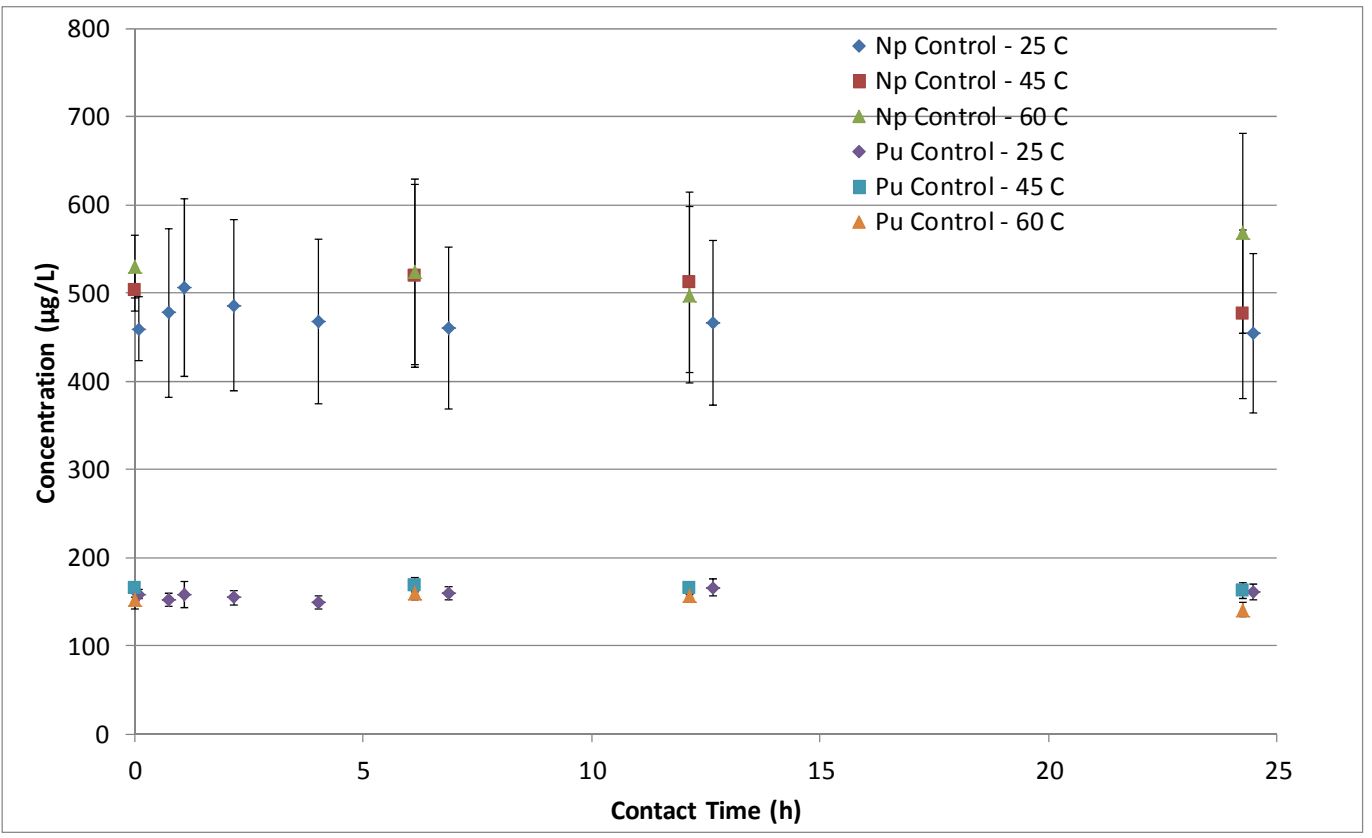

Figure A-7. $\mathrm{Np}$ and $\mathrm{Pu}$ concentrations in control samples from Tests 1-5 $\left(25^{\circ} \mathrm{C}\right), \mathbf{1 6}^{-20}$ $\left(45^{\circ} \mathrm{C}\right)$, and $21-25\left(60^{\circ} \mathrm{C}\right)$. 


\section{Distribution:}
A. B. Barnes, 999-W
S. D. Fink, 773-A
B. J. Giddings, 786-5A
C. C. Herman, 999-W
S. L. Marra, 773-A
F. M. Pennebaker, 773-42A
W. R. Wilmarth, 773-A
P. R. Jackson, DOE-SR, 703-46A
K. H. Subramanian, 249-8H
K. M. L. Taylor-Pashow, 773-A
D. T. Hobbs, 773-A
F. F. Fondeur, 773-A
T. B. Peters, $773-42 \mathrm{~A}$
E. J. Freed, 704-56H
D. J. Martin, 241-152H
K. L. Lang, 241-152H
B. A. Oard, 241-197H
R. E. Edwards, 707-7E
E. A. Brass, 249-8H
M. W. Geeting, 241-152H
S. P. McLeskey, 704-27S
S. P. Simner, 249-8H 